\title{
The Impact of America's Choice on Writing Performance in Georgia: First-Year Results
}

\author{
Henry May \\ Jonathan A. Supovitz \\ Joy Lesnick
}

July 2004

Consortium for Policy Research in Education

University of Pennsylvania Graduate School of Education 



\section{Contents}

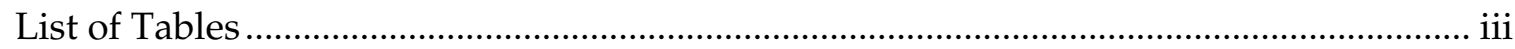

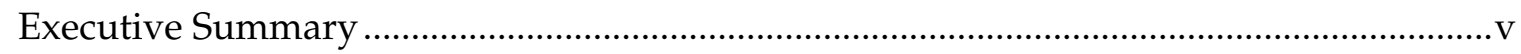

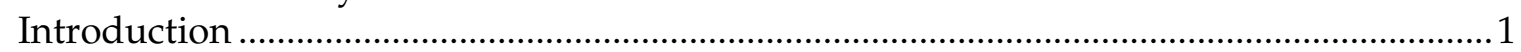

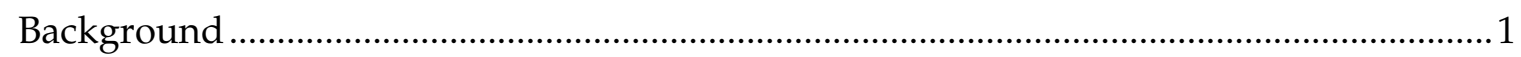

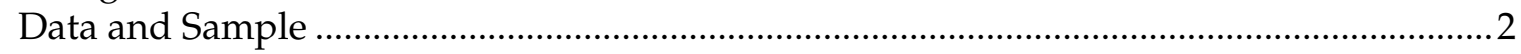

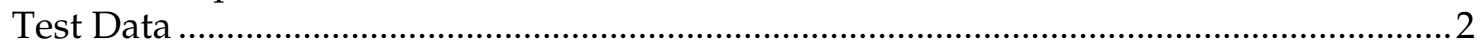

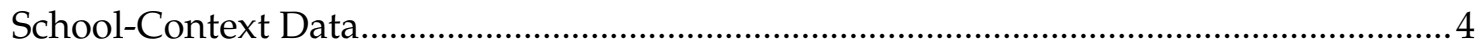

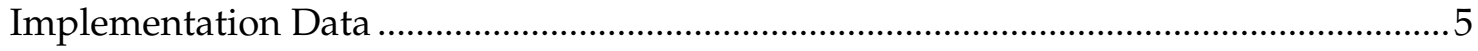

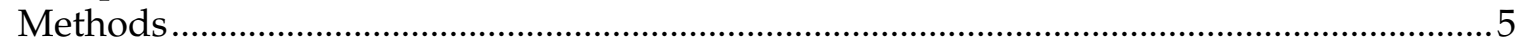

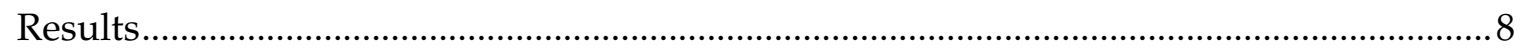

Impact of Georgia's Choice on Writing Scores............................................................ 8

Relationship Between Quality of Implementation and Impact of Georgia's Choice..... 10

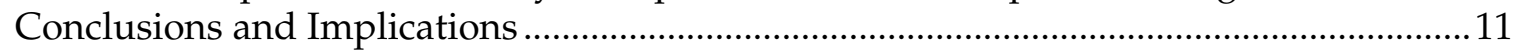

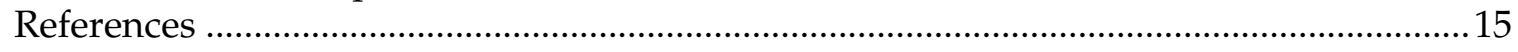

About the America's Choice Design ............................................................................... 17

About CPRE's Evaluation of America's Choice................................................................. 18

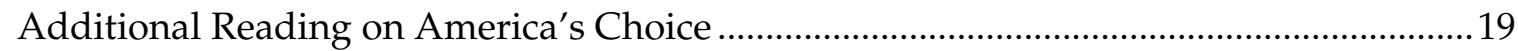

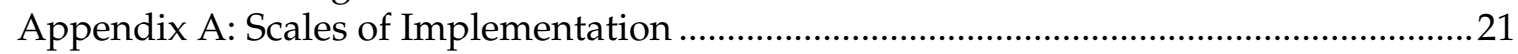

Appendix B: Results from Statistical Models of Impact ..................................................... 31

Appendix C: Results from Statistical Models Linking Implementation Measures and

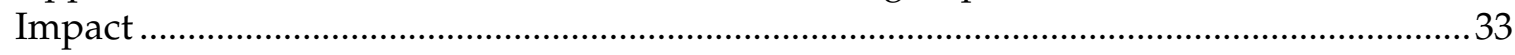

\section{List of Tables}

Table 1. Number of Students Tested in Writing ...................................................................

Table 2. Means and Standard Deviations of School-Context Variables for Georgia's

Choice and Other Schools ................................................................................................ 4

Table 3. Results of the Regression Model Predicting Baseline (2001) Writing Scores and

Change in Writing Scores (2001 to 2002) for Fifth and Eighth Grades .................................9

Table 4. Predicted Proportions of Fifth Graders at Various Proficiency Levels Before and

After the First Year of Georgia's Choice

Table 5. Predicted Proportions of Eighth Graders at Various Proficiency Levels Before

and After the First Year of Georgia's Choice

Table 6. Results of the Regression Model Predicting Change in Writing Scores (2001 to 2002) for Fifth Grade from Seven Implementation Factors. 


\section{Executive Summary}

During the first year of implementation, the emphasis of the America's Choice school reform design is an intensive focus on building students' writing skills. Writers workshop, the primary instructional emphasis of America's Choice during this year, is the component of the design for which teachers first receive in-depth training.

In keeping with the emphasis of America's Choice, this year-one external evaluation study of the impact of America's Choice on student performance in Georgia focuses on student writing performance. The study examines changes in student writing performance from 2001 to 2002, the initial year of implementation of America's Choice in 109 Georgia elementary schools and 50 Georgia middle schools. Because state writing assessments were administered to students in fifth and eighth grades, our analyses are restricted to these grade levels.

Overall, we found that students in America's Choice schools performed better on the state writing test than did students from similar Georgia schools. We found significantly greater gains in the writing performance of America's Choice schools in comparison to other Georgia schools, after adjusting for differences in prior school performance and a variety of school-level demographic characteristics. These effects were apparent in both the fifthand eighth-grade results. More specifically, the average Georgia's
Choice $^{1}$ elementary school had $20 \%$ more of its fifth-grade students scoring at the two highest levels of writing in 2001 than in 2002. Similar Georgia's Choice schools had a significantly lower increase of $17 \%$. For eighth grade, the average Georgia's Choice middle school had $29 \%$ more of its eighth-grade students scoring on target or better writing in 2001 than in 2002. Similar Georgia's Choice schools had a significantly lower increase of $25 \%$. This suggests that while there was a sizeable improvement in writing performance statewide in Georgia, the improvements for Georgia's Choice schools were even larger than the trends for similar schools throughout the state.

This study also contains exploratory results of the relationships between America's Choice school-level implementation measures and student learning. These measures are designed to assess schools' implementation on a variety of dimensions including understanding of the design, school and classroom implementation components, data use, parental involvement, and leadership. We found that none of these implementation indicators were reliable predictors of student achievement. Only in eighth grade did one of these implementation indicators - the use of data for planning and instruction have a statistically significant relationship with gains in student test performance. This finding provides evidence in support of the substantial emphasis on ongoing student assessment that is part of the America's Choice design. However, our inability to detect relationships between achievement gains and other implementation indicators may be due

\footnotetext{
${ }^{1}$ In Georgia, the America's Choice comprehensive school reform design was renamed Georgia's Choice.
} 
to invariance in, or inaccuracy of, the measures. Therefore, while these results do not suggest that any particular component of the design is unimportant, they do provide evidence of sizeable program effects and they identify a particularly powerful component of the design related to these effects. 


\section{Introduction}

In this study, we investigate the impact of America's Choice on student writing performance in Georgia. The analyses in this study focus on the change that occurred during the first year of implementation, the 2001-2002 school year. Two research questions guided these analyses:

- What effect did Georgia's Choice have on the writing scores from the state assessment?

- To what extent is the effect of Georgia's Choice related to implementation of specific components of the design?

The data sources for this study were individual-level student test scores on the Georgia writing assessments, schoolcontext measures (e.g., poverty rate, ethnic composition, etc.), and implementation data collected via a survey of cluster leaders, school principals, and the school leadership teams.

This report is organized into six sections. In the next section, we present some background on Georgia's Choice and the rollout of the design during the first year. Then we describe our data sources and sample. Next, we describe our methods, and then we present the results of our analyses. Finally, we offer some interpretations of the results and explore the implications of these results for Georgia schools, America's Choice, and for comprehensive school reform in general.

\section{Background}

In the spring of 2001, the Georgia State Board of Education contracted with the National Center on Education and the Economy (NCEE) to provide America's Choice to approximately 160 struggling elementary and middle schools throughout Georgia. This largescale implementation was coordinated by both NCEE and the Georgia Department of Education (GA-DOE) and renamed Georgia's Choice. At the end of the first year, 109 elementary schools and 50 middle schools had implemented the first stages of the design.

The rollout of America's Choice in Georgia focused on implementation of the writing and skills blocks during the first year. Implementation of the reading components did not begin until the end of the school year at the earliest, well after the state test had been administered. Math components of America's Choice were not implemented in the first year for elementary schools, and only two math core assignments were used during the first year in middle schools. These two core assignments were not used in prealgebra or algebra classes.

Implementation of the writing and skills components of America's Choice in elementary schools began in third and fourth grades, then expanded to include second and fifth grades, then proceeded to first and sixth grades. In middle schools, implementation of the writing and skills components of America's Choice began in eighth grade and expanded to seventh, then sixth grades. Because Georgia's Choice focused so specifically on writing in the first year, we restrict this year's study of impact to student writing scores. 
Further analyses by CPRE in coming years will examine the impact of the design on student reading and mathematics scores in Georgia as those components of the design are implemented.

\section{Data and Sample}

Three sources of data were used in these analyses. Student scores on the Georgia writing assessment for all students in fifth and eighth grades during the 2000-2001 and 2001-2002 school years were obtained from state databases. School-level variables providing information about the educational context of each school in the state was collected from the GA-DOE website. Implementation of the America's Choice design was measured through a survey administered by NCEE to Georgia's Choice cluster leaders, principals, and school leadership teams.

\section{Test Data}

Student writing performance was represented by student-level scores on state writing assessments. Table 1 shows the number of students taking the writing tests in grades 5 and 8 the year before Georgia's Choice began, and after one year of implementation.

The GA-DOE descriptions of the grade 5 writing assessment and the middle grades writing assessment (eighth grade) are as follows.

The writing assessment for grade 5 consists of an evaluation of student response to an assigned prompt. Students are assigned a topic in one of two genres, imaginative story or personal narrative. Papers are scored by trained raters using a standardized scoring system. The papers are evaluated to determine the developmental stage that the writing represents. There are six developmental stages.

\section{Stage 1: The Emerging Writer}

- Little or no topic development, organization, and/or detail.

- Little awareness of audience or writing task.

- Errors in surface features prevent the reader from understanding the writer's message.

Table 1. Number of Students Tested in Writing

\begin{tabular}{lcccc}
\hline & \multicolumn{2}{c}{ Fifth Grade } & \multicolumn{2}{c}{ Eighth Grade } \\
& $\begin{array}{l}\text { Prior to } \\
\text { Georgia's Choice }\end{array}$ & $\begin{array}{c}\text { One Year into } \\
\text { Georgia's Choice }\end{array}$ & $\begin{array}{c}\text { Prior to } \\
\text { Georgia's Choice }\end{array}$ & $\begin{array}{c}\text { One Year into } \\
\text { Georgia's Choice }\end{array}$ \\
\hline $\begin{array}{l}\text { Georgia's Choice } \\
\text { Schools }\end{array}$ & 9,668 & 9,448 & 9,371 & 9,627 \\
Other Schools & 100,735 & 100,247 & 87,998 & 89,535 \\
\hline
\end{tabular}




\section{Stage 2: The Developing Writer}

- Topic beginning to be developed. Response contains the beginning of an organization plan.

- Limited awareness of audience and/or task.

- Simple word choice and sentence patterns.

- Errors in surface features interfere with communication.

\section{Stage 3: The Focusing Writer}

- Topic clear even though development is incomplete. Plan apparent although ideas are loosely organized.

- $\quad$ Sense of audience and/or task.

- Minimal variety of vocabulary and sentence patterns.

- Errors in surface features interrupt the flow of communication.

\section{Stage 4: The Experimenting Writer}

- Topic clear and developed (development may be uneven). Clear plan with beginning, middle, and end (beginning and/or ending may be clumsy).

- Written for an audience.

- Experiments with language and sentence patterns. Word combinations and word choice may be novel.

- Errors in surface features may interrupt the flow of communication.

\section{Stage 5: The Engaging Writer}

- Topic well developed. Clear beginning, middle, and end. Organization sustains the writer's purpose.

- $\quad$ Engages the reader.

- $\quad$ Effective use of varied language and sentence patterns.

- Errors in surface features do not interfere with meaning.

\section{Stage 6: The Extending Writer}

- Topic fully elaborated with rich details. Organization sustains the writer's purpose and moves the reader through the piece.

- Engages and sustains the reader's interest.

- Creative and novel use of language and effective use of varied sentence patterns.

- Errors in surface features do not interfere with meaning.

The Georgia middle grades writing assessment is an evaluation of eighthgrade students' written responses to an assigned topic. In responding to the assigned topic within a two-hour timed period, the students are given the choice of writing a narrative story, an expository report, or a persuasive essay. The student responses are read by trained raters and evaluated in the areas of content/organization, style, sentence formation, usage, and mechanics. The students receive feedback in the form of a scale score ranging from 300 to 400 , performance scores in each of the areas 
Table 2. Means and Standard Deviations of School-Context Variables for Georgia's Choice and Other Schools

\begin{tabular}{|c|c|c|c|c|}
\hline & $\begin{array}{c}\text { Georgia's Choice } \\
\text { Elementary } \\
\text { Schools } \\
(\mathrm{N}=109)\end{array}$ & $\begin{array}{c}\text { Other } \\
\text { Elementary Schools } \\
(\mathrm{N}=963)\end{array}$ & $\begin{array}{l}\text { Georgia's } \\
\text { Choice Middle } \\
\text { Schools } \\
(N=50)\end{array}$ & $\begin{array}{c}\text { Other } \\
\text { Middle Schools } \\
(\mathrm{N}=356)\end{array}$ \\
\hline$\overline{\text { School Size }}$ & $\begin{array}{l}528 \\
(221)\end{array}$ & $\begin{array}{c}597 \\
(238)\end{array}$ & $\begin{array}{c}722 \\
(295)\end{array}$ & $\begin{array}{c}836 \\
(363)\end{array}$ \\
\hline Percent Minority & $\begin{array}{c}79 \\
(27)\end{array}$ & $\begin{array}{c}48 \\
(32)\end{array}$ & $\begin{array}{c}77 \\
(23)\end{array}$ & $\begin{array}{c}41 \\
(28)\end{array}$ \\
\hline $\begin{array}{l}\text { Percent Retained } \\
\text { in Grade }\end{array}$ & $\begin{array}{l}3 \\
(3)\end{array}$ & $\begin{array}{l}3 \\
(3)\end{array}$ & $\begin{array}{c}5 \\
(3)\end{array}$ & $\begin{array}{c}3 \\
(3)\end{array}$ \\
\hline $\begin{array}{l}\text { Percent Free/Reduced- } \\
\text { Price Lunch Eligible }\end{array}$ & $\begin{array}{c}87 \\
(15)\end{array}$ & $\begin{array}{l}53 \\
(28)\end{array}$ & $\begin{array}{c}75 \\
(12)\end{array}$ & $\begin{array}{c}46 \\
(23)\end{array}$ \\
\hline $\begin{array}{l}\text { Percent Limited English } \\
\text { Proficient }\end{array}$ & $\begin{array}{c}4 \\
(8)\end{array}$ & $\begin{array}{l}3 \\
(6)\end{array}$ & $\begin{array}{c}1 \\
(4)\end{array}$ & $\begin{array}{c}2 \\
(3)\end{array}$ \\
\hline $\begin{array}{l}\text { Percent Special } \\
\text { Education }\end{array}$ & $\begin{array}{l}12 \\
(5)\end{array}$ & $\begin{array}{l}12 \\
(4)\end{array}$ & $\begin{array}{l}13 \\
(4)\end{array}$ & $\begin{array}{l}13 \\
(4)\end{array}$ \\
\hline Average Teacher Salary & $\begin{array}{l}42,053 \\
(2,421)\end{array}$ & $\begin{array}{l}43,543 \\
(2,686)\end{array}$ & $\begin{array}{l}42,050 \\
(2,328)\end{array}$ & $\begin{array}{l}43,389 \\
(2,579)\end{array}$ \\
\hline $\begin{array}{l}\text { Average Teacher Years } \\
\text { of Experience }\end{array}$ & $\begin{array}{l}12 \\
(2)\end{array}$ & $\begin{array}{l}13 \\
(3)\end{array}$ & $\begin{array}{l}13 \\
(3)\end{array}$ & $\begin{array}{l}12 \\
(2)\end{array}$ \\
\hline Pupil/Teacher Ratio & $\begin{array}{l}17 \\
(3)\end{array}$ & $\begin{array}{l}16 \\
(3)\end{array}$ & $\begin{array}{l}16 \\
(2)\end{array}$ & $\begin{array}{l}16 \\
(2)\end{array}$ \\
\hline $\begin{array}{l}\text { Average Fifth-Grade } \\
\text { Writing Level for } \\
\text { 2000-2001 }\end{array}$ & $\begin{array}{c}3.9 \\
(0.2)\end{array}$ & $\begin{array}{c}4.2 \\
(0.4)\end{array}$ & & \\
\hline $\begin{array}{l}\text { Percent Meeting or } \\
\text { Exceeding the Eighth- } \\
\text { Grade Writing Standard } \\
\text { for } 2000-2001\end{array}$ & & & $\begin{array}{l}72 \\
(9)\end{array}$ & $\begin{array}{l}84 \\
(9)\end{array}$ \\
\hline
\end{tabular}

evaluated, and total performance level of not on target, on target, and exceeds target. Only the performance-level scores were available for individual students. The scale scores are not used in this study.

\section{School-Context Data}

School-level variables providing information about the educational context of each school included information about the demographic composition of the student body, teacher characteristics, and the previous writing performance of students in each school. Table 2 shows the means and standard deviations for these schoollevel variables for Georgia's Choice and other schools for the 2001-2002 school year, along with the writing scores for the 2000-2001 school year. 
On average, the Georgia's Choice schools are very similar to the comparison schools on 9 of the 11 school-context variables. The only practical differences are that the Georgia's Choice schools have higher concentrations of minority students, and they also have higher concentrations of students from poor families. There is also a slight difference in the average teacher salary. Teachers in the comparisons schools are paid about $3.5 \%$ more than teachers in the Georgia's Choice schools.

\section{Implementation Data}

In an effort to measure the implementation of the America's Choice design, NCEE administered a survey, called the Diagnostic and Assessment Tool (DAT), to Georgia's Choice schools. Responses to implementation items were on a five-point scale ranging from not in place to fully implemented.

Responses to other items were on a fivepoint scale ranging from strongly disagree to strongly agree. The responses to the survey for each school were arrived at through a consensus decision by cluster leaders, principals, and school leadership teams.

CPRE conducted factor analyses of the DAT data and derived seven scales from the survey responses. These were:

- Understanding of the America's Choice design,

- Implementation of school-level structural elements,

- Implementation of classroom-level structural elements,

- Use of data for planning and instruction,
- Parent and community involvement,

- Commitment to the design, and

- Active and effective leadership.

The items comprising these scales and estimates of the internal consistency (i.e., Cronbach's Alpha) for each of the seven scales are shown in Appendix A. For elementary schools, these reliabilities range from .69 to .88 . For middle schools, these reliabilities range from .68 to .86 .

\section{Methods}

In accordance with the two research questions stated in the introduction of this report, the analyses for this study proceeded in two stages. The first set of analyses compared the gains in writing scores from 2001 to 2002 for Georgia's Choice schools to other schools after controlling for prior performance and other school-level variables. The second set of analyses included only the Georgia's Choice schools and explored possible links between quality of implementation and outcomes. Both sets of analyses used the same analytic approach and similar statistical models for predicting gains in school-level performance from 2001 to 2002.

Ideally, an analysis of achievement gains would model change at the individual level (i.e., the student level). In order to do this, every student needs to be tested at least twice, before and after the implementation of the program. Unfortunately, the Georgia writing test was administered to fifth, eighth, and eleventh graders only. With no writing test in fourth or seventh grades, there is no available information about the writing performance of fifthand eighth-grade students at the end of 
the previous year (i.e., when they were in fourth or seventh grade). In fact, there was no statewide assessment in any subject administered to seventh graders during the 2000-2001 school year. There was an assessment administered to fourth graders called the Criterion Referenced Competency Test, which includes reading and English/language arts components. Therefore, a reading or language arts score could be used as a control variable for the fifth-grade writing scores. Unfortunately, difficulties in obtaining data that included consistent student identifiers across years prohibited this type of analysis.

Fortunately, we were able to develop an alternative analytical approach that is able to model schoollevel changes in writing scores using individual students' writing scores and school-level variables. This approach enabled us to compare changes in writing scores at the school level, while controlling for differences in the characteristics of the student populations in the schools along with other school characteristics. More importantly, because the dependent variable in these analyses is the individual student score, there was no loss of precision usually associated with the use of school-level aggregates of student-level scores (e.g., school average scores, percent proficient, etc.). In essence, the model we developed compares sequential cohorts of students within schools, and the impact estimates produced show effects at the school level. ${ }^{2}$

\footnotetext{
${ }^{2}$ Although the analysis of individual change is often preferred for impact analyses, an analysis of sequential cohorts is appropriate here given that the impact estimate pertains to change at the school level, and the sequential cohorts within each school are nearly identical in terms of size, ethnic composition, and poverty rates.
}

The student-level achievement scores in these data were nested within schools, so a two-level hierarchical model (Raudenbush \& Bryk, 2002) was used in these analyses. Furthermore, because the achievement scores were coded as ordered categories of proficiency, an ordinal logistic regression model was used to model differences in achievement scores. In order to model change in writing scores from 2001 to 2002 for a particular grade level, all students tested in that grade in both years were included in the analysis. An indicator variable signifying the year in which the student was tested was included as a random effect at Level 1 (coded 1 for 2002 and 0 for 2001). At Level 2, the school-context variables are each centered around their grand means (see Raudenbush \& Bryk, 2002, pp. 31-35 for a discussion of centering and its implications). Adapting the notation of Raudenbush and Bryk (2002) with some modifications that simplify the formulas, the general analytic model had the mathematical form shown on page 7 .

On the left side of the equation for Level 1 is the formula for the log-odds for observing a score greater than or equal to $m$. This is equal to the natural logarithm of the probability of observing a score greater than or equal to $m$ divided by the probability of observing a score less than $m$. The Level 1 intercept (i.e., $\beta_{0 j}$ ) shows the overall baseline achievement for school $j$ (i.e., before the implementation of Georgia's Choice). The Level 1 slope (i.e., $\beta_{l j}$ ) shows the change in the overall baseline achievement for school $j$ during the first year of Georgia's Choice. The final term shows the difference in the log-odds of 
Level 1:

$$
\ln \left(\frac{\operatorname{Prob}\left(Y_{i j} \geq m\right)}{\operatorname{Prob}\left(Y_{i j}<m\right)}\right)=\beta_{0 j}+\beta_{1 j} Y E A R_{i j}+\delta_{m}
$$

Level 2:

$$
\begin{aligned}
& \beta_{0 j}=\gamma_{00}+\boldsymbol{\Gamma}_{0} \mathbf{X}_{\mathbf{j}}+\gamma_{01}(\text { Georgia'sChoice })+u_{0 j} \\
& \beta_{1 j}=\gamma_{10}+\gamma_{11}(2001 \text { school average writing score })_{j}+\boldsymbol{\Gamma}_{1} \mathbf{X}_{\mathbf{j}}+\gamma_{12}(\text { Georgia'sChoice })+u_{1 j}
\end{aligned}
$$

observing scores in $M-2$ adjacent categories for school $j$. Note that the probability of observing a score of 1 or higher is $100 \%$ (i.e., $\operatorname{Prob}\left(Y_{i j} \geq 1\right)=1$ ); therefore, this model treats writing scores equal to 1 as the reference category, and $\delta_{6}$ is set equal to 0 to define the model.

In the first equation at Level 2, the overall baseline achievement for the $J$ schools (i.e., $\beta_{0 j}$ ) is modeled as an average baseline achievement for nonGeorgia's Choice schools (i.e., $\gamma_{00}$ ), plus a vector of fixed effects (i.e., $\Gamma_{0} \mathbf{X}_{\mathbf{j}}$ ) for the context variables of school $j$, plus an effect of Georgia's Choice status (i.e., $\left.\gamma_{01}\right)$, plus a residual term (i.e., $u_{0 j}$ ) for school $j$.

In the second equation at Level 2, the change in overall achievement for the $J$ schools (i.e., $\beta_{l j}$ ) is modeled as an average change for non-Georgia's Choice schools (i.e., $\gamma_{10}$ ), plus an effect of initial school achievement (i.e., $\gamma_{11}$ ), plus a vector of fixed effects (i.e., $\Gamma_{1} \mathbf{X}_{\mathbf{j}}$ ) for the context variables of school $j$, plus an effect of Georgia's Choice status (i.e., $\gamma_{12}$ ), plus a residual term (i.e., $u_{1 j}$ ) for school $j$.

In the first stage of analyses, the indicator variable representing each school's participation status in Georgia's
Choice included in both Level 2

equations produced estimates of the differences in baseline achievement between Georgia's Choice schools and other schools before the implementation of Georgia's Choice (i.e., $\gamma_{01}$ ), and the differences between Georgia's Choice schools and other schools in the change in achievement from 2001 to 2002 (i.e., $\left.\gamma_{12}\right)$.

Effect sizes from these models represent differences in log-odds. The effects are usually exponentiated to produce odds ratios. While this is appropriate for the estimate of baseline differences, it is not helpful for interpreting the differences in gains (i.e., exponentiation would produce a ratio of odds ratios). Therefore, to aid in interpretation of these effect estimates, the estimates from the model are used to produce expected proportions of students scoring at each proficiency level for 2000-2001 and 2001-2002. These are much easier to interpret, and they make the magnitude of the effect more evident.

In the second stage of the analysis, factor scores for the seven implementation scales were included as fixed effects predicting change in achievement from 2001 to 2002 for the Georgia's Choice schools. Due to high 
correlations between the implementation scales and the potential for collinearity, we decided to run separate models for each of the seven implementation variables. These models included the same control variables as in the first stage, along with a single implementation variable predicting differences in achievement gains only, not differences in initial status. Any implementation variables found to have significant relationships with writing score gains were then reanalyzed after controlling for other implementation factors. This was done to determine the extent to which significant relationships were due to general implementation quality or to the quality of implementation for specific components of Georgia's Choice.

All models were estimated via penalized quasi-likelihood as implemented in HLM version 5.05 (Raudenbush, Bryk, \& Congdon, 2001).

\section{Results}

In this section, we present the results from both stages of analyses. First, we report the results of our impact analysis, addressing the first research question, which focuses on the gains in student writing scores associated with participation in Georgia's Choice. Then we report the results of our implementation analyses, addressing the second research question, which focuses on possible links between variation in the quality of implementation of Georgia's Choice and variation in the gains experienced by Georgia's Choice schools.

\section{Impact of Georgia's Choice on Writing Scores}

Estimates of the impact of Georgia's Choice on writing scores were produced separately for fifth and eighth grades. This was done by including in both Level 2 equations of the general analytic model an indicator variable coded 1 for Georgia's Choice schools and 0 for comparison schools. Table 3 shows the estimates of baseline differences and program impact (i.e., gains) for Georgia's Choice schools for the fifth and eighth grades. The full models are shown in Appendix B. ${ }^{3}$

For the fifth-grade model, these estimates show that, after controlling for several school characteristics, the baseline writing scores of Georgia's Choice elementary schools (i.e., before implementation) were not significantly different from non-Georgia's Choice schools, and the gains in writing scores for Georgia's Choice elementary schools after one year of implementation were significantly greater than the gains experienced by non-Georgia's Choice schools throughout the state. More specifically, during the 2001-2002 school year, Georgia's Choice elementary schools experienced significantly greater increases in the proportion of fifth graders scoring in higher writing

\footnotetext{
${ }^{3}$ The robustness of these effect estimates to model misspecification (e.g., nonlinearities, omitted interactions) was evaluated by running each model using subsets of the full sample after stratifying on prior achievement, ethnic composition, and poverty rates. Estimates of the effects of Georgia's Choice on test score improvements were nearly identical to those from the full models for all models run for both fifth and eighth grades. The estimates were statistically significant for all four models run for fifth grade, and significant for two out of four models run for eighth grade. Note that the sample of schools is much smaller at eighth grade.
} 
Table 3. Results of the Regression Model Predicting Baseline (2001) Writing Scores and Change in Writing Scores (2001 to 2002) for Fifth and Eighth Grades

\begin{tabular}{lcc}
\hline & $\begin{array}{c}\text { Regression } \\
\text { Coefficient }\end{array}$ & $\begin{array}{c}\text { Standard } \\
\text { Error }\end{array}$ \\
\hline $\begin{array}{l}\text { Difference in Fifth-Grade Writing Scores Prior to Georgia's } \\
\text { Choice }\end{array}$ & -0.03 & 0.05 \\
$\begin{array}{l}\text { Difference in 2001-2002 Gains for Fifth-Grade Writing Scores } \\
\text { Difference in Eighth-Grade Writing Scores Prior to Georgia's } \\
\text { Choice }\end{array}$ & $0.16 *$ & 0.06 \\
$\begin{array}{l}\text { Difference in 2001-2002 Gains for Eighth-Grade Writing } \\
\text { Scores }\end{array}$ & $0.17 * *$ & 0.08 \\
\end{tabular}

$* p<.05, * * p<.01$

proficiency categories than similar schools not participating in Georgia's Choice.

For the eighth-grade model, these estimates show that, after controlling for several school characteristics, the writing scores of Georgia's Choice middle schools for the 2000-2001 school year (i.e., before implementation) were significantly lower than those from nonGeorgia's Choice schools, and the gains in writing scores for Georgia's Choice middle schools after one year of implementation were significantly greater than non-Georgia's Choice schools. More specifically, during the 2001-2002 school year, Georgia's Choice middle schools experienced significantly greater increases in the proportion of students scoring in higher writing proficiency categories than similar schools not participating in Georgia's Choice.

The magnitude of these effect estimates may be more easily understood when represented in terms of the expected proportions of students scoring at each proficiency level in the baseline year and also after one year of implementation of Georgia's Choice. Table 4 shows these proportions for the fifth grade as predicted by the statistical analysis. Whereas the proportion of students at each proficiency category is

Table 4. Predicted Proportions of Fifth Graders at Various Proficiency Levels Before and After the First Year of Georgia's Choice

\begin{tabular}{|c|c|c|c|c|c|c|}
\hline & \multicolumn{6}{|c|}{ Writing Proficiency Level } \\
\hline & 1 & 2 & 3 & 4 & 5 & 6 \\
\hline $\begin{array}{l}\text { Average of Georgia's Choice Schools } \\
\text { (before implementation) 2000-2001 } \\
\text { (after one year) 2001-2002 }\end{array}$ & $\begin{array}{l}2 \\
1\end{array}$ & $\begin{array}{l}7 \\
3\end{array}$ & $\begin{array}{l}36 \\
18\end{array}$ & $\begin{array}{l}41 \\
45\end{array}$ & $\begin{array}{l}12 \\
27\end{array}$ & $\begin{array}{l}2 \\
7\end{array}$ \\
\hline $\begin{array}{l}\text { Average of Similar Comparison Schools } \\
\qquad \begin{aligned} 2000-2001 \\
2001-2002\end{aligned}\end{array}$ & $\begin{array}{l}2 \\
1\end{array}$ & $\begin{array}{l}7 \\
3\end{array}$ & $\begin{array}{l}35 \\
19\end{array}$ & $\begin{array}{l}41 \\
46\end{array}$ & $\begin{array}{l}12 \\
25\end{array}$ & $\begin{array}{l}2 \\
6\end{array}$ \\
\hline
\end{tabular}


Table 5. Predicted Proportions of Eighth Graders at Various Proficiency Levels Before and After the First Year of Georgia's Choice

\begin{tabular}{ccccc}
\hline & \multicolumn{3}{c}{ Writing Proficiency Level } \\
\cline { 3 - 5 } & & 1 & 2 & 3 \\
\cline { 3 - 5 } & & & \\
Average of Georgia's Choice Schools & & & \\
(before implementation) & $2000-2001$ & 52 & 47 & 2 \\
(after one year) $2001-2002$ & 22 & 73 & 5 \\
Average of Similar Comparison Schools & $2000-2001$ & 47 & 51 & 2 \\
& $2001-2002$ & 22 & 73 & 5 \\
\hline
\end{tabular}

nearly the same for the baseline year (2000-2001) for both Georgia's Choice schools and comparison schools with similar characteristics, the Georgia's Choice schools have $20 \%$ more students at levels 5 and 6 after one year compared to an increase of $17 \%$ for similar Georgia schools.

Table 5 shows these proportions for the eighth grade as predicted by the statistical analysis. The average Georgia's Choice middle school had $29 \%$ more of its eighth-grade students scoring on target or better writing in 2001 than in 2002. Similar Georgia's Choice schools had a significantly lower increase of $25 \%$. In other words, whereas the proportion of students scoring proficient (i.e., levels 2 and 3 ) is lower in Georgia's Choice schools during the baseline year (2000-2001), the Georgia's Choice schools have caught up to the comparison schools with similar characteristics after one year of implementation.

This suggests that while there was a sizeable improvement in writing performance statewide in Georgia, the improvements for Georgia's Choice schools were even larger than the trends for similar schools throughout the state.

\section{Relationship Between Quality of Implementation and Impact of Georgia's Choice}

Estimates of the degree to which the quality of implementation in Georgia's Choice schools was related to their gains in fifth- and eighth-grade writing scores were also produced. The seven measures of implementation described earlier were used in these analyses. Each measure was scaled to have a mean of 0 and a standard deviation of 1 , so that regression coefficients show the change in odds per standard deviation in each implementation measure. These results are shown in Table 6 with the full models shown in Appendix C.

Use of data for planning and instruction among middle schools was the only implementation measure shown to have a significant relationship with gains in writing scores. Georgia's Choice schools with a score of one standard deviation above the mean on the data-use scale had a $13 \%$ greater odds ratio $\left(\mathrm{e}^{.12}=1.13\right)$ of students scoring in higher writing proficiency categories than Georgia's Choice schools with an average score on the data-use scale. This 
Table 6. Results of the Regression Model Predicting Change in Writing Scores (2001 to 2002) for Fifth Grade from Seven Implementation Factors

\begin{tabular}{lll}
\hline & $\begin{array}{c}\text { Regression } \\
\text { Coefficient }\end{array}$ & $\begin{array}{c}\text { Standard } \\
\text { Error }\end{array}$ \\
\hline Fifth Grade & & \\
Understanding of the America's Choice Design & .00 & .05 \\
School-Level Structural Elements & .02 & .05 \\
Classroom-Level Structural Elements & .02 & .05 \\
Use of Data for Planning and Instruction & -.01 & .05 \\
Parent and Community Involvement & .01 & .05 \\
Commitment to the Design & .00 & .05 \\
Active and Effective Leadership & .06 & .05 \\
& & \\
Eighth Grade & & \\
Understanding of the America's Choice Design & -.02 & .07 \\
School-Level Structural Elements & -.03 & .06 \\
Classroom-Level Structural Elements & -.04 & .08 \\
Use of Data for Planning and Instruction & $.12 *$ & .05 \\
Parent and Community Involvement & .00 & .06 \\
Commitment to the Design & .00 & .06 \\
Active and Effective Leadership & .09 & .06 \\
\hline${ }^{*}<.05$ & &
\end{tabular}

translates to $4 \%$ more students scoring on target or above for Georgia's Choice schools one standard deviation above the mean on use of data for planning and instruction, and $6 \%$ more students scoring on target or above for Georgia's Choice schools two standard deviations above the mean on use of data for planning and instruction.

The relationship between data use for planning and instruction and gains in middle school writing scores remained significant after controlling for the six other implementation measures. In fact, the parameter estimate of the effect of this variable increased to .23 $(\mathrm{p}<.01)$ after including these additional control variables. This suggests that, for middle schools in Georgia, data use was important as a distinct component of the America's Choice design, potentially driving a significant portion of the gains experienced by schools participating in Georgia's Choice.

\section{Conclusions and Implications}

The results of this study suggest two things. First, the America's Choice design as implemented in elementary and middle schools in Georgia produced significant gains on the state's writing assessments. Second, those middle schools participating in Georgia's Choice that had greater use of data for planning and instruction experienced greater gains in writing scores. These findings provide additional evidence that the America's Choice comprehensive school reform design has had a positive impact on the performance of students and schools across the nation.

The effect sizes for this study are small relative to accepted standards in statistics (Cohen, 1988). However, it is generally the case that moderate or large effects are rare in large-scale education 
research. For example, Borman, Hewes, Overman, and Brown (2003), in their meta-analysis of research on the impacts of comprehensive school reform, found that even the most effective designs produced only small effects over the course of one year. Fortunately, these effects cumulate over the course of time, and as Borman and Hewes (2002) demonstrate, these positive impacts can lead to considerable differences in the educational outcomes of many students.

In previous studies conducted as part of CPRE's evaluation of America's Choice, it was usually the case that greater effects were seen in elementary grades, rather than in middle grades. This may not be the case in this study, simply due to the fact that the design was implemented longer in the eighth grade than in the fifth grade. As noted in this report, implementation of the design in elementary schools began in fourth grade and expanded to fifth grade. In middle schools, implementation began in the eighth grade, so the program was in place longer in eighth grade than in fifth grade. As such, we might begin to see larger effects for the elementary grades as implementation continues.

It is interesting that the use of data for planning and instruction appeared as an important predictor of writing score gains among Georgia's Choice schools. The fact that this relationship grew even stronger when other measures of implementation were held constant suggests that data use is important as a distinct component of the design. In other words, data use does not come automatically when schools implement the design; however, when schools use data for planning and instruction, regardless of their implementation of other components, they experience greater gains. The support for this conclusion is somewhat fragile because a similar relationship was not found for fifth-grade writing scores. Nevertheless, these results are very interesting to say the least, and further research on schools' and teachers' use of data is surely a promising venture.

The apparent lack of relationships between implementation measures and outcomes is also interesting. However, we are not surprised by this lack of relationships. In a previous study, we discovered that the majority of the variation in implementation of America's Choice occurred among teachers within schools, not between schools (Supovitz \& May, in press). The lack of relationships between schoollevel implementation and outcomes may be due to a lack of variation in implementation at the school level. In other words, the variation in implementation among schools may be quite small relative to the variation in implementation among teachers. Given the absence of teacher-level data from this study, evaluation of this hypothesis must be left for future research.

It is important to consider the limitations of this study when interpreting its results. Specifically, there are three limitations worth discussing here. First, this study is an observational quasi-experiment; it is not a randomized experiment. However, as Cook (2002) points out, while such quasi-experimental studies may be less efficient than randomized experiments, there is no evidence to suggest that they systematically underestimate or overestimate effects. A second limitation is related to the fact that student-level demographics were not included as control variables in these analyses. Yet, 
given the differences between Georgia's Choice schools and comparison schools, inclusion of these student-level controls would most likely increase the effect estimates. Lastly, and most importantly, this study is limited by the fact that it does not model individual change. That is, each student in these analyses is tested only once, so there is no direct measure of the increase in writing skills for any particular student. Nevertheless, these analyses do model school-level change, and given that most states' accountability systems focus on schoollevel scores for particular grades, this type of change is important. The de facto assumption that accompanies such a school-level change analysis is that the differences between cohorts of students in the same school are relatively small. In other words, it is assumed that the performance of eighth graders in 2001 is a good indicator of the performance of eighth graders in 2002 in the absence of any intervention. Given the relative homogeneity of schools and the fact that the demographics of schools usually change very slowly (which is the case for these data), we believe this assumption is a reasonable one.

In summary, the results of this study suggest that Georgia's Choice has had a positive impact on writing scores in the fifth and eighth grades. This is a very promising finding given that, to date, this is the largest scale-up of a comprehensive school reform model within a single site. 


\section{References}

Borman, G. D., \& Hewes, G. M. (2002).

Long-term effects and cost-effectiveness of Success for All. Educational Evaluation and Policy Analysis, 24(4), 243-266.

Borman, G. D., Hewes, G. M., Overman, L. T., \& Brown, S. (2003).

Comprehensive school reform and achievement: A meta-analysis. Review of Educational Research, 73(2), 125-230.

Cohen, J. (1988). Statistical power analysis for the social sciences (2nd edition). Hillsdale, NJ: Lawrence Erlbaum Associates.

Cook, T. D. (2002). Randomized experiments in education: Why are they so rare? Educational Evaluation and Policy Analysis, 24(3), 175-199.

National Center on Education and the Economy. (n.d.). America's Choice:

Program overview. Retrieved August 28, 2003, from http:/ / www.ncee.org/ acsd/.

Raudenbush, S. W., \& Bryk, A. S. (2002). Hierarchical linear models: Applications and data analysis methods (2nd edition).

Thousand Oaks, CA: Sage Publications.

Raudenbush, S. W., Bryk, A. S., \&

Congdon, R. (2001). HLM (Version 5.05) [Computer Software]. Lincolnwood, IL: Scientific Software International.

Supovitz, J. A., \& May, H. (in press). A study of the links between implementation and effectiveness of the America's Choice comprehensive school reform design. Journal of Education for Students Placed At Risk. 


\section{About the America's Choice Design}

The America's Choice school design is a $\mathrm{K}-12$ comprehensive school reform model developed by the National Center on Education and the Economy (NCEE). America's Choice is a wellestablished school reform model currently being implemented in over 500 schools across the nation. America's Choice focuses on raising academic achievement by providing a rigorous standards-based curriculum and safety nets for all students. A stated goal of the design is "to ensure that every student is successful on state and local assessments and prepared for college" (NCEE, n.d.).

America's Choice does not offer schools a script or a paint-by-numbers approach to reformed instruction. America's Choice recognizes that the pace of change will vary from school to school and, thus, the model does not have a rigid implementation schedule. Rather, the core of the America's Choice design contains a set of principles about the purpose of schooling and how schools should operate, and it provides a set of tools for building a program based on those principles. These essential principles and tools include:

- High expectations for all students, with communication of those expectations through explicit performance standards that are aligned to assessments and include examples of student work that meet the standards. These New Standards Performance Standards provide a common set of expectations for students and teachers.
- The implementation of standardsbased literacy, math, and skills blocks, which happen every day for every child, and dramatically change teaching and learning in every classroom. The rituals and routines associated with these blocks are designed to prepare students to deal with demanding content and become independent learners.

- A common core curriculum that is aligned with the standards. Through the America's Choice literacy workshops, core assignments, and foundations of advanced mathematics, school life is organized around a core curriculum. These curricular components are designed to help students develop key skills, convey core concepts, and apply what they know.

- Ongoing assessment of students in order to inform daily instruction through the use of standards-based assessments, including the New Standards Reference Examination, which are aligned with the standards and the core curriculum and provide detailed feedback to teachers and students about student skill levels in relation to the standards.

- School-embedded, ongoing, teacher professional development led by a full-time literacy coach and designed to strengthen teachers' knowledge of the America's Choice approach to teaching and learning. This includes learning how to conduct a close analysis of their students' work in relation to standards, and using this knowledge to develop lessons calibrated to the needs of different students. 
- "Safety nets," including tutoring and course recovery programs, that are structured into the school day and school year, and that provide students with extensive support and multiple opportunities to achieve the standards.

- A school leadership team, led by the principal and subject-matter coaches, that coordinates implementation through a variety of means. These include setting performance targets and analyzing student work on a variety of measures, training teachers, adjusting school schedules, and implementing safety-net programs to provide time for students to receive additional instruction.

In order to become an America's Choice school, over $80 \%$ of a school's faculty must indicate their commitment to the America's Choice design and agree to implement the program over three years. Each school must assign personnel as coaches to lead the implementation of the design, and a parent/community outreach coordinator to ensure that students get needed support services.

\section{About CPRE's Evaluation of America's Choice}

The Consortium for Policy Research in Education (CPRE) at the University of Pennsylvania was contracted by NCEE in 1998 to conduct the external evaluation of the America's Choice school design. Each year, CPRE designs and conducts a series of targeted studies on the implementation and impacts of the America's Choice design.
The publication of this report follows the release of several other studies by CPRE on the implementation and impact of America's Choice across the nation using both qualitative and quantitative methods. Those previous reports can be viewed as separate pieces or as complements to the information presented in this report.

The purpose of CPRE's evaluation is to provide formative feedback to NCEE and America's Choice schools about emerging trends in the implementation of the design, and to seek evidence of the impacts of the design using accepted high standards of evaluation design and analysis methodologies.

CPRE's evaluation of America's Choice is guided by three overarching evaluation questions. First, is America's Choice being carried out in the manner envisioned - that is, how are teachers and school administrators understanding and implementing the many facets of the America's Choice reform design? Second, as a result of their implementation of America's Choice, are the instructional practices of teachers changing in ways that would improve student learning? Third, do America's Choice schools experience improvements in student achievement, and to what degree can changes in student performance be attributed to the design? Within this framework, annual evaluation studies target specific aspects of the America's Choice design for more in-depth investigation.

To address these questions, the CPRE evaluation team gathers a broad array of qualitative and quantitative data to develop a rich and valid picture of the implementation process over time and to capture the impacts of the design 
on students and teachers. Data sources include:

- Surveys of teachers and administrators in America's Choice schools nationwide.

- Site visits to schools across the nation to observe classroom instruction, examine implementation artifacts, and interview teachers, students, and school administrators.

- Telephone interviews with NCEE staff, school faculty members, and school and district administrators.

- Document reviews.

- Observations of national, regional, and school-level professional development.

- Collection of student performance measures, including state and local tests, the New Standards Reference Examination, and more authentic samples of student work products.

After data collection, CPRE evaluation team members analyze the data using appropriate qualitative and quantitative research techniques in order to identify patterns of intended and unintended consequences and to detect effects of the design on students, teachers, and schools. The results are reported in a series of thematic evaluation reports that are released each year.

\section{Additional Reading on America's Choice}

The following reports are currently available from CPRE. Print copies are available at no cost by emailing cpre@gse.upenn.edu, or by calling 215573-0700. Copies can also be downloaded at www.cpre.org/ Research/Research_Project_America's_ Choice.htm.

- A Longitudinal Study of the Impact of America's Choice on Student Performance in Rochester, New York, 1998-2003 (Henry May, Jonathan A. Supovitz, and David Perda, July 2004)

- Mapping a Course for Improved Student Learning: How Innovative Schools Systematically Use Student Performance Data to Guide Improvement (Jonathan A. Supovitz and Valerie Klein, November 2003)

- Teacher and Coach Implementation of Writers Workshop in America's Choice Schools, 2001 and 2002 (Amy J. Bach and Jonathan A. Supovitz, October 2003)

- The Heart of the Matter: The Coaching Model in America's Choice Schools (Susan M. Poglinco, Amy J. Bach, Kate Hovde, Sheila Rosenblum, Marisa Saunders, and Jonathan A. Supovitz, May 2003)

- The Relationship Between Teacher Implementation of America's Choice and Student Learning in Plainfield, New Jersey (Jonathan A. Supovitz and Henry May, January 2003)

- Impact of America's Choice on Student Performance in Duval County, Florida (Jonathan A. Supovitz, Brooke Snyder Taylor, and Henry May, October 2002) 
- Implementation of the America's Choice Literacy Workshops

(Jonathan A. Supovitz, Susan M.

Poglinco, and Amy J. Bach, April

2002)

- Instructional Leadership in a Standards-Based Reform (Jonathan A. Supovitz and Susan M. Poglinco, December 2001)

- Moving Mountains: Successes and Challenges of the America's Choice Comprehensive School Reform Design (Jonathan A. Supovitz, Susan M. Poglinco, and Brooke Snyder, March 2001)

- America's Choice Comprehensive School Reform Design: First-Year Implementation Evaluation Summary (Thomas Corcoran, Margaret Hoppe, Theresa Luhm, and Jonathan A. Supovitz, February 2000) 


\section{Appendix A: Scales of Implementation}

Table A1. Factors, Items, and Estimates of Internal Consistency for the Elementary School Implementation Survey - Primary

\footnotetext{
\begin{tabular}{lc}
\hline Elementary Scales and Items & $\begin{array}{c}\text { Cronbach's } \\
\text { Alpha }\end{array}$ \\
\hline
\end{tabular}

Factor 1: Understanding of the America's Choice design

Teachers and administrators understand the connections between state/district content standards and the New Standards Performance Standards.

There is a high level of understanding of the America's Choice design among staff in target primary classrooms.

There is a high level of understanding of the America's Choice design among all staff at this school.

There is a high level of understanding of the America's Choice design among students.

There is a high level of understanding of the America's Choice design among parents/guardians and the local community.

Factor 2: Implementation of school-level structural elements

The whole school community implements the 25-Book Campaign.

A Principal-sponsored Book-of-the-Month program is in place.

Exhibits of student work that approaches or meets the standards, along with appropriate standards and elements, are displayed on bulletin boards in classrooms and halls.

Model literacy classrooms are established at the second and fourth grades and Skills Block in a kindergarten/first-grade classroom.

The Upper-Elementary Coach implements small group and tutorial programs for students needing assistance with print/sound code.

Summer literacy catch-ups are planned for students who are significantly below standard in literacy.

Time is scheduled for meetings of teams of grade-level and same-subject teachers.

The master schedule includes a $21 / 2$-hour Literacy Block and a 1-hour Mathematics Block, and time is scheduled for meetings of grade-level and same-subject teachers.

Class teachers are identified who will teach the same students for the next 2-3 years and allocated to teaching teams for the commencement of the following school year.

There are scheduled Study Group meetings of teachers to read and discuss monographs.

There are scheduled Teacher Meetings, coordinated by the Coaches, focusing on classroom teaching and learning.
} 
Table A1. Factors, Items, and Estimates of Internal Consistency for the Elementary School Implementation Survey - Primary (continued)

Teachers in target classrooms (10 per coach) use the New Standards Performance Standards for English/language arts and the primary literacy standards to plan instruction and to develop lessons.

Teachers in target classrooms implement one Genre Study at each grade level.

Teachers in target primary classrooms (grades K-2) implement the Skill Development Block and the Writers and Readers Workshops as set up in the model literacy classrooms.

Teachers in target classrooms collect sample pieces of writing for each student on at least three occasions during the year and analyze them for growth.

Students in target classrooms are matched to text level.

\section{Factor 4: Use of data for planning and instruction}

Teachers in target classrooms evaluate student work in English/language arts using the New Standards Performance Standards for English/language arts and the primary literacy standards.

Results on the previous year's state assessments are analyzed to reveal strengths and weaknesses, to guide instruction, and to plan for results in the current year.

Teachers in target classrooms use the America's Choice performance standards and the elements to provide feedback to students and to guide instruction.

Teachers in target classrooms take Running Records on each student on at least three occasions during the year and analyze them for growth.

The Leadership Team uses "Planning for Results" in creating the School Plan.

The Leadership Team reviews results from the Diagnostic and Assessment Tool to evaluate progress in implementing the design.

\section{Factor 5: Parent and community involvement}

The School Plan is endorsed by stakeholders (district, staff, parents, and partners).

The Parent/Community Outreach Coordinator communicates with parents regarding the changes that are being implemented in the school and the reasons for the changes.

There is a high level of involvement of parents/guardians in the 25-Book Campaign and in reading to their children.

Teachers use the Home-School Notebooks to communicate with parents/guardians on a regular basis.

The local community and school partners are aware and supportive of the standardsbased reforms that the school is implementing.

The local community and school partners provide tangible support to the school in increasing the number of books in classrooms. 
Table A1. Factors, Items, and Estimates of Internal Consistency for the Elementary School Implementation Survey - Primary (continued)

\section{Factor 6: Commitment to the design}

There is a high level of commitment to the America's Choice design among staff in target primary classrooms.

There is a high level of commitment to the America's Choice design among staff in target upper-elementary classrooms.

There is a high level of commitment to the America's Choice design among all staff.

There is a high level of commitment to the America's Choice design among students.

There is a high level of commitment to the America's Choice design among parents/guardians and the local community.

Factor 7: Active and effective leadership

The Principal takes the lead role in advocating and implementing the design.

The Principal visits classrooms daily, inspecting the standard of student work and talking to students about the quality of their work.

The Principal coaches and mentors staff, providing feedback on classroom visits and on her/his analysis of student performance.

The Leadership Team is established, including the Principal, Assistant Principal, Primary Coach, Upper-Elementary Coach, and Parent/Community Outreach Coordinator.

The Leadership Team meets regularly with set agendas that focus on implementation of the design.

There is effective distributed leadership at this school in initiating and implementing the America's Choice design. 
Table A2. Factors, Items, and Estimates of Internal Consistency for the Elementary School Implementation Survey - Upper Elementary

Elementary Scales and Items
Factor 1: Understanding of the America's Choice design
Teachers and administrators understand the connections between state/district content
standards and the New Standards Performance Standards.
There is a high level of understanding of the America's Choice design among staff in
target upper-elementary classrooms.
There is a high level of understanding of the America's Choice design among all staff at
this school.
There is a high level of understanding of the America's Choice design among students.
There is a high level of understanding of the America's Choice design among
parents/guardians and the local community.
Factor 2: Implementation of school-level structural elements
The whole school community implements the 25-Book Campaign.
A Principal-sponsored Book-of-the-Month program is in place.
Exhibits of student work that approaches or meets the standards, along with appropriate
standards and elements, are displayed on bulletin boards in classrooms and halls.

Model literacy classrooms are established at the second and fourth grades and Skills Block in a kindergarten/first-grade classroom.

The Upper-Elementary Coach implements small group and tutorial programs for students needing assistance with print/sound code.

Summer literacy catch-ups are planned for students who are significantly below standard in literacy.

Time is scheduled for meetings of teams of grade-level and same-subject teachers.

The master schedule includes a 2 1/2-hour Literacy Block and a 1-hour Mathematics Block, and time is scheduled for meetings of grade-level and same-subject teachers.

Class teachers are identified who will teach the same students for the next 2-3 years and allocated to teaching teams for the commencement of the following school year.

There are scheduled Study Group meetings of teachers to read and discuss monographs.

There are scheduled Teacher Meetings, coordinated by the Coaches, focusing on classroom teaching and learning. 
Table A2. Factors, Items, and Estimates of Internal Consistency for the Elementary School Implementation Survey - Upper Elementary (continued)

Elementary Scales and Items
Factor 3: Implementation of classroom-level structural elements
Teachers in target classrooms (10 per coach) use the New Standards Performance
Standards for English/language arts and the primary literacy standards to plan instruction
and to develop lessons.
Teachers in target classrooms implement one Genre Study at each grade level.
Teachers in target upper-elementary classrooms (grades 3-5) implement the Readers and
Writers Workshops as set up in the model literacy classrooms.

Teachers in target classrooms collect sample pieces of writing for each student on at least three occasions during the year and analyze them for growth.

Students in target classrooms are matched to text level.

Factor 4: Use of data for planning and instruction

Teachers in target classrooms evaluate student work in English/language arts using the New Standards Performance Standards for English/language arts and the primary literacy standards.

Results on the previous year's state assessments are analyzed to reveal strengths and weaknesses, to guide instruction, and to plan for results in the current year.

Teachers in target classrooms use the America's Choice performance standards and the elements to provide feedback to students and to guide instruction.

Teachers in target classrooms take Running Records on each student on at least three occasions during the year and analyze them for growth.

The Leadership Team uses "Planning for Results" in creating the School Plan.

The Leadership Team reviews results from the Diagnostic and Assessment Tool to evaluate progress in implementing the design.

\section{Factor 5: Parent and community involvement}

The School Plan is endorsed by stakeholders (district, staff, parents, and partners).

The Parent/Community Outreach Coordinator communicates with parents regarding the changes that are being implemented in the school and the reasons for the changes.

There is a high level of involvement of parents/guardians in the 25-Book Campaign and in reading to their children.

Teachers use the Home-School Notebooks to communicate with parents/guardians on a regular basis.

The local community and school partners are aware and supportive of the standardsbased reforms that the school is implementing.

The local community and school partners provide tangible support to the school in increasing the number of books in classrooms. 
Table A2. Factors, Items, and Estimates of Internal Consistency for the Elementary School Implementation Survey - Upper Elementary (continued)

Elementary Scales and Items

Cronbach's

Alpha

Factor 6: Commitment to the design

0.8835

There is a high level of commitment to the America's Choice design among staff in target primary classrooms.

There is a high level of commitment to the America's Choice design among staff in target upper-elementary classrooms.

There is a high level of commitment to the America's Choice design among all staff.

There is a high level of commitment to the America's Choice design among students.

There is a high level of commitment to the America's Choice design among parents/guardians and the local community.

Factor 7: Active and effective leadership

The Principal takes the lead role in advocating and implementing the design.

The Principal visits classrooms daily, inspecting the standard of student work and talking to students about the quality of their work.

The Principal coaches and mentors staff, providing feedback on classroom visits and on her/his analysis of student performance.

The Leadership Team is established, including the Principal, Assistant Principal, Primary Coach, Upper-Elementary Coach, and Parent/Community Outreach Coordinator.

The Leadership Team meets regularly with set agendas that focus on implementation of the design.

There is effective distributed leadership at this school in initiating and implementing the America's Choice design. 
Table A3. Factors, Items, and Estimates of Internal Consistency for the Middle School Implementation Survey

\begin{tabular}{lc}
\hline Middle School Scales and Items & Cronbach's Alpha \\
\hline Factor 1: Understanding of the America's Choice design & 0.8624
\end{tabular}

Teachers and administrators understand the connections between their state/district content standards and the New Standards Performance Standards.

There is a high level of understanding of the America's Choice design among English teachers in target classrooms.

There is a high level of understanding of the America's Choice design among Math teachers in target classrooms.

There is a high level of understanding of the America's Choice design among all staff at this school.

There is a high level of understanding of the America's Choice design among students.

There is a high level of understanding of the America's Choice design among parents/guardians and the local community.

\section{Factor 2: Implementation of school-level structural elements}

The whole school community implements the 25-Book Campaign.

A Book-of-the-Month program is implemented by the Principal and the Leadership Team.

Exhibits of student work that approaches or meets the standards, along with appropriate standards and elements, are displayed on bulletin boards in classrooms and halls.

Model literacy and math classroom is established at the eighth grade.

Summer literacy and math catch-ups are planned for students who are significantly below standard.

A plan is in place to ensure all classrooms have an adequate supply of leveled books for the next school year.

Class teachers are identified who will teach the same students for the next 2-3 years and allocated to teaching teams for the commencement of the following year.

There are scheduled Study Group meetings of teachers to read and discuss monographs.

There are scheduled Teacher Meetings, coordinated by the Coaches, focusing on classroom teaching and learning. 
Table A3. Factors, Items, and Estimates of Internal Consistency for the Middle School Implementation Survey (continued)

Middle School Scales and Items

Cronbach's Alpha

Factor 3: Implementation of classroom-level structural elements

0.6769

English teachers in target classrooms implement Genre Studies at the seventh- and eighth-grade levels.

English teachers in target seventh- and eighth-grade classrooms implement the Writers and Readers Workshops as set up in the model classroom.

Math teachers in target classrooms implement the rituals and routines and use of standards-based assignments as set up in the model classroom.

English teachers in target classrooms collect sample pieces of writing for each student on at least three occasions during the year and analyze them for growth.

Factor 4: Use of data for planning and instruction

0.7800

English and Math teachers in target classrooms evaluate student work using the New Standards Performance Standards and use the standards to guide the development of instruction.

Other subject area teachers identify subject area standards to use in planning for instruction and analyzing student work.

Results on the previous year's state/district assessments are analyzed to reveal strengths and weaknesses, to guide instruction, and to plan for results in the current year.

Results on the current year's state/district assessments are analyzed to review progress, set targets for individual classes and students, and plan for results in the following year.

Teachers in target classrooms use the America's Choice performance standards and the elements to provide feedback to students and to guide instruction.

The Leadership Team uses "Planning for Results" in creating the School Plan.

The Leadership Team reviews results from the Diagnostic and Assessment Tool to evaluate progress in implementing the design.

Factor 5: Parent and community involvement

The School Plan is endorsed by stakeholders (district, staff, parents, and partners).

The Leadership Team communicates with parents regarding the changes that are being implemented in the school and the reasons for the changes.

There is a high level of involvement of parents/guardians in the 25-Book Campaign.

Teachers use the Home-School Notebooks to communicate with parents/guardians on a regular basis.

The local community and school partners are aware and supportive of the standardsbased reforms that the school is implementing.

The local community and school partners provide tangible support to the school in increasing the number of books in classrooms. 
Table A3. Factors, Items, and Estimates of Internal Consistency for the Middle School Implementation Survey (continued)

Middle School Scales and Items

Cronbach's Alpha

Factor 6: Commitment to the design

0.7813

There is a high level of commitment to the America's Choice design among English teachers in target classrooms.

There is a high level of commitment to the America's Choice design among Math teachers in target classrooms.

There is a high level of commitment to the America's Choice design among all staff at this school.

There is a high level of commitment to the America's Choice design among students.

There is a high level of commitment to the America's Choice design among parents/guardians and the local community.

Factor 7: Active and effective leadership

The Principal and Assistant Principal take the lead role in advocating and implementing the design.

The Principal and Assistant Principal visit classrooms daily, inspecting the standard of student work and talking to students about the quality of their work.

The Principal and Assistant Principal coach and mentor staff, providing feedback on their classroom visits and on their analysis of student performance.

The Leadership Team is established, including the Principal, Assistant Principal (as Design Coach), Literacy Coach, Math Coach, and Parent/Community Outreach Coordinator.

The Leadership Team meets regularly with set agendas that focus on implementation of the design.

There is effective distributed leadership at this school in initiating and implementing the America's Choice design. 


\section{Appendix B: Results from Statistical Models of Impact}

Table B1. Regression Results of the Model Predicting Baseline (2001) Writing Scores and Change in Writing Scores (2001 to 2002) for the Fifth Grade

\begin{tabular}{|c|c|c|c|}
\hline Fixed Effect & Estimate & $\begin{array}{c}\text { Standard } \\
\text { Error }\end{array}$ & $\begin{array}{l}\text { Odds } \\
\text { Ratio }\end{array}$ \\
\hline \multicolumn{4}{|l|}{ Baseline Writing Scores in 2001} \\
\hline Intercept & $-2.49 * * *$ & 0.02 & 0.08 \\
\hline School Size (per 100 students) & 0.01 & 0.01 & 1.01 \\
\hline Percent Minority & $0.26 * *$ & 0.08 & 1.30 \\
\hline Percent Retained in Grade & $1.66 * *$ & 0.60 & 5.26 \\
\hline Percent Free/Reduced-Price Lunch Eligible & $-1.97 * * *$ & 0.10 & 0.14 \\
\hline Percent Limited English Proficient & -0.20 & 0.27 & 0.82 \\
\hline Percent Special Education & $-1.41 * * *$ & 0.37 & 0.24 \\
\hline Average Teacher Salary (in thousands of dollars) & $0.04 * * *$ & 0.01 & 1.04 \\
\hline Average Teacher Years of Experience & $-0.01 *$ & 0.01 & 0.99 \\
\hline Pupil/Teacher Ratio & -0.01 & 0.01 & 0.99 \\
\hline Baseline Difference for Georgia's Choice & -0.03 & 0.05 & 0.97 \\
\hline \multicolumn{4}{|l|}{ Change in Writing Scores from 2001 to 2002} \\
\hline Intercept & $0.38 * * *$ & 0.02 & 1.46 \\
\hline School Size (per 100 students) & -0.01 & 0.01 & 0.99 \\
\hline Percent Minority & $-0.38 * * *$ & 0.10 & 0.68 \\
\hline Percent Retained in Grade & -0.44 & 0.75 & 0.64 \\
\hline Percent Free/Reduced-Price Lunch Eligible & $1.05 * * *$ & 0.14 & 2.86 \\
\hline Percent Limited English Proficient & -0.12 & 0.33 & 0.89 \\
\hline Percent Special Education & 0.07 & 0.46 & 1.07 \\
\hline Average Teacher Salary (in thousands of dollars) & $-0.02^{\sim}$ & 0.00 & 0.98 \\
\hline Average Teacher Years of Experience & -0.01 & 0.01 & 0.99 \\
\hline Pupil/Teacher Ratio & 0.01 & 0.01 & 1.01 \\
\hline Average Fifth-Grade Writing Level for 2000-2001 & $0.88 * * *$ & 0.06 & 2.41 \\
\hline Difference in Gains for Georgia's Choice & $0.16^{*}$ & 0.06 & 1.17 \\
\hline \multicolumn{4}{|l|}{ Thresholds } \\
\hline$\delta_{5}$ & $1.89 * * *$ & 0.01 & \\
\hline$\delta_{4}$ & $3.89 * * *$ & 0.01 & \\
\hline$\delta_{3}$ & $5.92 * * *$ & 0.01 & \\
\hline$\delta_{2}$ & $7.39 * * *$ & 0.03 & \\
\hline Random Effect & $\begin{array}{c}\text { Variance } \\
\text { Component } \\
\end{array}$ & & \\
\hline Baseline Writing Scores (2001) & $0.18 * * *$ & & \\
\hline Change in Writing Scores (2001-2002) & $0.26 * * *$ & & \\
\hline
\end{tabular}

$\sim p<.10, * p<.05, * * p<.01, * * * p<.001$ 
Table B2. Regression Results of the Model Predicting Baseline (2001) Writing Scores and Change in Writing Scores (2001 to 2002) for the Eighth Grade

\begin{tabular}{|c|c|c|c|}
\hline Fixed Effect & Estimate & $\begin{array}{c}\text { Standard } \\
\text { Error }\end{array}$ & $\begin{array}{l}\text { Odds } \\
\text { Ratio }\end{array}$ \\
\hline \multicolumn{4}{|l|}{ Baseline Writing Scores in 2001} \\
\hline Intercept & $-2.39 * * *$ & 0.02 & 0.09 \\
\hline School Size (per 100 students) & 0.01 & 0.01 & 1.01 \\
\hline Percent Minority & 0.18 & 0.13 & 1.20 \\
\hline Percent Retained in Grade & -0.91 & 0.88 & 0.40 \\
\hline Percent Free/Reduced-Price Lunch Eligible & $-2.39 * * *$ & 0.18 & 0.09 \\
\hline Percent Limited English Proficient & $-1.45^{\sim}$ & 0.79 & 0.23 \\
\hline Percent Special Education & $-1.91 * *$ & 0.70 & 0.15 \\
\hline Average Teacher Salary (in thousands of dollars) & $0.03 *$ & 0.01 & 1.03 \\
\hline Average Teacher Years of Experience & -0.01 & 0.01 & 0.99 \\
\hline Pupil/Teacher Ratio & $-0.04 * *$ & 0.01 & 0.96 \\
\hline Baseline Difference for Georgia's Choice & $-0.17^{*}$ & 0.08 & 0.84 \\
\hline \multicolumn{4}{|l|}{ Change in Writing Scores from 2001 to 2002} \\
\hline Intercept & $0.13 * * *$ & 0.18 & 1.14 \\
\hline School Size (per 100 students) & $-0.01 *$ & 0.01 & 0.99 \\
\hline Percent Minority & -0.02 & 0.10 & 0.98 \\
\hline Percent Retained in Grade & $-1.74 *$ & 0.67 & 0.18 \\
\hline Percent Free/Reduced-Price Lunch Eligible & $-0.36 *$ & 0.16 & 0.70 \\
\hline Percent Limited English Proficient & -0.78 & 0.58 & 0.46 \\
\hline Percent Special Education & -0.52 & 0.56 & 0.59 \\
\hline Average Teacher Salary (in thousands of dollars) & 0.01 & 0.01 & 1.01 \\
\hline Average Teacher Years of Experience & -0.01 & 0.01 & 0.99 \\
\hline Pupil/Teacher Ratio & $-0.04 * *$ & 0.01 & 0.96 \\
\hline Average Eighth-Grade Writing Level for 2000-2001 & $-0.94 * * *$ & 0.17 & 0.39 \\
\hline Difference in Gains for Georgia's Choice & $0.17 * *$ & 0.06 & 1.19 \\
\hline \multicolumn{4}{|l|}{ Threshold } \\
\hline$\delta_{2}$ & $4.11 * * *$ & 0.01 & \\
\hline Random Effect & $\begin{array}{c}\text { Variance } \\
\text { Component }\end{array}$ & & \\
\hline Baseline Writing Scores (2001) & $0.17 * * *$ & & \\
\hline Change in Writing Scores (2001-2002) & $0.06 * * *$ & & \\
\hline
\end{tabular}

$\sim p<.10, * p<.05, * * p<.01, * * * p<.001$ 


\section{Appendix C: Results from Statistical Models Linking Implementation Measures and Impact}

Table C1. Regression Results for Implementation of "Classroom-Level Structural Elements" in the Fifth Grade

\begin{tabular}{|c|c|c|c|}
\hline Fixed Effect & Estimate & $\begin{array}{c}\text { Standard } \\
\text { Error }\end{array}$ & $\begin{array}{l}\text { Odds } \\
\text { Ratio }\end{array}$ \\
\hline \multicolumn{4}{|l|}{ Baseline Writing Scores in 2001} \\
\hline Intercept & $-3.24 * * *$ & 0.05 & 0.04 \\
\hline School Size (per 100 students) & -0.00 & 0.00 & 1.00 \\
\hline Percent Minority & -0.11 & 0.25 & 0.90 \\
\hline Percent Retained in Grade & 0.74 & 1.50 & 2.10 \\
\hline Percent Free/Reduced-Price Lunch Eligible & $-0.86 *$ & 0.43 & 0.42 \\
\hline Percent Limited English Proficient & -0.87 & 0.58 & 0.42 \\
\hline Percent Special Education & $-2.26 *$ & 1.05 & 0.10 \\
\hline Average Teacher Salary (in thousands of dollars) & -0.00 & 0.00 & 1.00 \\
\hline Average Teacher Years of Experience & 0.03 & 0.03 & 1.03 \\
\hline Pupil/Teacher Ratio & -0.00 & 0.02 & 1.00 \\
\hline \multicolumn{4}{|l|}{ Change in Writing Scores from 2001 to 2002} \\
\hline Intercept & $0.54 * * *$ & 0.05 & 1.72 \\
\hline School Size (per 100 students) & -0.00 & 0.00 & 1.00 \\
\hline Percent Minority & $-0.51 \sim$ & 0.27 & 0.60 \\
\hline Percent Retained in Grade & $-3.07 \sim$ & 1.71 & 0.05 \\
\hline Percent Free/Reduced-Price Lunch Eligible & 0.05 & 0.47 & 1.05 \\
\hline Percent Limited English Proficient & -0.73 & 0.64 & 0.48 \\
\hline Percent Special Education & $-3.08 *$ & 1.20 & 0.05 \\
\hline Average Teacher Salary (in thousands of dollars) & 0.00 & 0.00 & 1.00 \\
\hline Average Teacher Years of Experience & 0.01 & 0.03 & 1.01 \\
\hline Pupil/Teacher Ratio & $0.07 * * *$ & 0.02 & 1.07 \\
\hline Average Fifth-Grade Writing Level for $2000-2001$ & $-0.95 * * *$ & 0.24 & 0.39 \\
\hline Classroom-Level Structural Elements - Grade 5 & 0.02 & 0.05 & 1.02 \\
\hline \multicolumn{4}{|l|}{ Thresholds } \\
\hline$\delta_{5}$ & $2.03 * * *$ & 0.04 & \\
\hline$\delta_{4}$ & $4.11 * * *$ & 0.06 & \\
\hline$\delta_{3}$ & $6.09 * * *$ & 0.09 & \\
\hline$\delta_{2}$ & $7.50 * * *$ & 0.14 & \\
\hline Random Effect & $\begin{array}{c}\text { Variance } \\
\text { Component }\end{array}$ & & \\
\hline Baseline Writing Scores (2001) & $0.35 * * *$ & & \\
\hline Change in Writing Scores (2001-2002) & $0.34 * * *$ & & \\
\hline
\end{tabular}

$\tilde{\sim}<.10, * p<.05, * * p<.01, * * * p<.001$ 
Table C2. Regression Results for Implementation of "Classroom-Level Structural Elements" in the Eighth Grade

\begin{tabular}{|c|c|c|c|}
\hline Fixed Effect & Estimate & $\begin{array}{c}\text { Standard } \\
\text { Error }\end{array}$ & $\begin{array}{l}\text { Odds } \\
\text { Ratio }\end{array}$ \\
\hline \multicolumn{4}{|l|}{ Baseline Writing Scores in 2001} \\
\hline Intercept & $-3.22 * * *$ & 0.06 & 0.04 \\
\hline School Size (per 100 students) & -0.00 & 0.00 & 1.00 \\
\hline Percent Minority & $-0.80 *$ & 0.32 & 0.45 \\
\hline Percent Retained in Grade & -1.50 & 1.59 & 0.22 \\
\hline Percent Free/Reduced-Price Lunch Eligible & $-1.51 *$ & 0.69 & 0.22 \\
\hline Percent Limited English Proficient & -0.04 & 1.53 & 0.96 \\
\hline Percent Special Education & -0.67 & 1.68 & 0.51 \\
\hline Average Teacher Salary (in thousands of dollars) & 0.00 & 0.00 & 1.00 \\
\hline Average Teacher Years of Experience & -0.01 & 0.03 & 0.99 \\
\hline Pupil/Teacher Ratio & 0.06 & 0.04 & 1.06 \\
\hline \multicolumn{4}{|l|}{ Change in Writing Scores from 2001 to 2002} \\
\hline Intercept & $0.30 * * *$ & 0.07 & 1.35 \\
\hline School Size (per 100 students) & -0.00 & 0.00 & 1.00 \\
\hline Percent Minority & 0.80 & 0.48 & 2.23 \\
\hline Percent Retained in Grade & -0.56 & 2.28 & 0.57 \\
\hline Percent Free/Reduced-Price Lunch Eligible & -0.00 & 1.02 & 1.00 \\
\hline Percent Limited English Proficient & 0.57 & 2.23 & 1.77 \\
\hline Percent Special Education & -0.01 & 2.42 & 0.99 \\
\hline Average Teacher Salary (in thousands of dollars) & -0.00 & 0.00 & 1.00 \\
\hline Average Teacher Years of Experience & -0.01 & 0.04 & 0.99 \\
\hline Pupil/Teacher Ratio & -0.09 & 0.06 & 0.91 \\
\hline Average Eighth-Grade Writing Level for 2000-2001 & $2.12 * *$ & 0.71 & 8.33 \\
\hline Classroom-Level Structural Elements - Grade 8 & -0.04 & 0.08 & 0.96 \\
\hline \multicolumn{4}{|l|}{ Threshold } \\
\hline$\delta_{2}$ & $4.18 * * *$ & 0.04 & \\
\hline Random Effect & $\begin{array}{l}\text { Variance } \\
\text { Component }\end{array}$ & & \\
\hline Baseline Writing Scores (2001) & $0.07 * * *$ & & \\
\hline Change in Writing Scores (2001-2002) & $0.13 * * *$ & & \\
\hline
\end{tabular}

$\sim p<.10, * p<.05, * * p<.01, * * * p<.001$ 
Table C3. Regression Results for Implementation of "Commitment to the Design" in the Fifth Grade

\begin{tabular}{|c|c|c|c|}
\hline Fixed Effect & Estimate & $\begin{array}{c}\text { Standard } \\
\text { Error }\end{array}$ & $\begin{array}{l}\text { Odds } \\
\text { Ratio }\end{array}$ \\
\hline \multicolumn{4}{|l|}{ Baseline Writing Scores in 2001} \\
\hline Intercept & $-3.25 * * *$ & 0.05 & 0.04 \\
\hline School Size (per 100 students) & -0.00 & 0.00 & 1.00 \\
\hline Percent Minority & -0.12 & 0.25 & 0.89 \\
\hline Percent Retained in Grade & 0.74 & 1.52 & 2.10 \\
\hline Percent Free/Reduced-Price Lunch Eligible & $-0.87 *$ & 0.43 & 0.42 \\
\hline Percent Limited English Proficient & -0.86 & 0.58 & 0.42 \\
\hline Percent Special Education & $-2.27 *$ & 1.05 & 0.10 \\
\hline Average Teacher Salary (in thousands of dollars) & -0.00 & 0.00 & 1.00 \\
\hline Average Teacher Years of Experience & 0.03 & 0.03 & 1.03 \\
\hline Pupil/Teacher Ratio & -0.00 & 0.02 & 1.00 \\
\hline \multicolumn{4}{|l|}{ Change in Writing Scores from 2001 to 2002} \\
\hline Intercept & $0.54 * * *$ & 0.05 & 1.72 \\
\hline School Size (per 100 students) & -0.00 & 0.00 & 1.00 \\
\hline Percent Minority & $-0.51 \sim$ & 0.27 & 0.60 \\
\hline Percent Retained in Grade & $-3.01 \sim$ & 1.71 & 0.05 \\
\hline Percent Free/Reduced-Price Lunch Eligible & 0.14 & 0.48 & 1.15 \\
\hline Percent Limited English Proficient & -0.66 & 0.64 & 0.52 \\
\hline Percent Special Education & $-2.85 \sim$ & 1.21 & 0.06 \\
\hline Average Teacher Salary (in thousands of dollars) & 0.00 & 0.00 & 1.00 \\
\hline Average Teacher Years of Experience & 0.01 & 0.03 & 1.01 \\
\hline Pupil/Teacher Ratio & $0.07 * * *$ & 0.02 & 1.07 \\
\hline Average Fifth-Grade Writing Level for $2000-2001$ & $-0.81 * * *$ & 0.25 & 0.44 \\
\hline Commitment to the Design - Grade 5 & 0.00 & 0.05 & 1.00 \\
\hline \multicolumn{4}{|l|}{ Thresholds } \\
\hline$\delta_{5}$ & $2.04 * * *$ & 0.03 & \\
\hline$\delta_{4}$ & $4.12 * * *$ & 0.04 & \\
\hline$\delta 3$ & $6.09 * * *$ & 0.05 & \\
\hline$\delta_{2}$ & $7.51 * * *$ & 0.08 & \\
\hline Random Effect & $\begin{array}{c}\text { Variance } \\
\text { Component }\end{array}$ & & \\
\hline Baseline Writing Scores (2001) & $0.13 * * *$ & & \\
\hline Change in Writing Scores (2001-2002) & $0.12 * * *$ & & \\
\hline
\end{tabular}

$\sim p<.10, * p<.05, * * p<.01, * * * p<.001$ 
Table C4. Regression Results for Implementation of "Commitment to the Design" in the Eighth Grade

\begin{tabular}{|c|c|c|c|}
\hline Fixed Effect & Estimate & $\begin{array}{l}\text { Standard } \\
\text { Error }\end{array}$ & $\begin{array}{l}\text { Odds } \\
\text { Ratio }\end{array}$ \\
\hline \multicolumn{4}{|l|}{ Baseline Writing Scores in 2001} \\
\hline Intercept & $-3.22 * * *$ & 0.06 & 0.04 \\
\hline School Size (per 100 students) & -0.00 & 0.00 & 1.00 \\
\hline Percent Minority & $-0.80 \sim$ & 0.32 & 0.45 \\
\hline Percent Retained in Grade & -1.50 & 1.59 & 0.22 \\
\hline Percent Free/Reduced-Price Lunch Eligible & $-1.52 *$ & 0.69 & 0.22 \\
\hline Percent Limited English Proficient & -0.02 & 1.53 & 0.98 \\
\hline Percent Special Education & -0.66 & 1.68 & 0.52 \\
\hline Average Teacher Salary (in thousands of dollars) & 0.00 & 0.00 & 1.00 \\
\hline Average Teacher Years of Experience & -0.01 & 0.03 & 0.99 \\
\hline Pupil/Teacher Ratio & 0.06 & 0.04 & 1.06 \\
\hline \multicolumn{4}{|l|}{ Change in Writing Scores from 2001 to 2002} \\
\hline Intercept & $0.31 * * *$ & 0.07 & 1.36 \\
\hline School Size (per 100 students) & -0.00 & 0.00 & 1.00 \\
\hline Percent Minority & $0.89 \sim$ & 0.49 & 2.44 \\
\hline Percent Retained in Grade & -0.49 & 2.35 & 0.61 \\
\hline Percent Free/Reduced-Price Lunch Eligible & 0.12 & 1.04 & 1.13 \\
\hline Percent Limited English Proficient & 0.85 & 2.23 & 2.34 \\
\hline Percent Special Education & 0.68 & 2.45 & 1.97 \\
\hline Average Teacher Salary (in thousands of dollars) & -0.00 & 0.00 & 1.00 \\
\hline Average Teacher Years of Experience & -0.01 & 0.05 & 0.99 \\
\hline Pupil/Teacher Ratio & -0.07 & 0.06 & 0.93 \\
\hline Average Eighth-Grade Writing Level for 2000-2001 & $2.32 * *$ & 0.74 & 10.18 \\
\hline Commitment to the Design - Grade 8 & 0.00 & 0.06 & 1.00 \\
\hline \multicolumn{4}{|l|}{ Threshold } \\
\hline$\delta_{2}$ & $4.18 * * *$ & 0.04 & \\
\hline Random Effect & $\begin{array}{c}\text { Variance } \\
\text { Component }\end{array}$ & & \\
\hline Baseline Writing Scores (2001) & $0.67 * * *$ & & \\
\hline Change in Writing Scores (2001-2002) & $0.15 * * *$ & & \\
\hline
\end{tabular}

$\sim p<.10, * p<.05, * * p<.01, * * * p<.001$ 
Table C5. Regression Results for Implementation of "Use of Data for Planning and Instruction" in the Fifth Grade

\begin{tabular}{|c|c|c|c|}
\hline Fixed Effect & Estimate & $\begin{array}{c}\text { Standard } \\
\text { Error }\end{array}$ & $\begin{array}{l}\text { Odds } \\
\text { Ratio }\end{array}$ \\
\hline \multicolumn{4}{|l|}{ Baseline Writing Scores in 2001} \\
\hline Intercept & $-3.24 * * *$ & 0.05 & 0.04 \\
\hline School Size (per 100 students) & -0.00 & 0.00 & 1.00 \\
\hline Percent Minority & -0.12 & 0.24 & 0.89 \\
\hline Percent Retained in Grade & 0.71 & 1.50 & 2.03 \\
\hline Percent Free/Reduced-Price Lunch Eligible & $-0.86 *$ & 0.43 & 0.42 \\
\hline Percent Limited English Proficient & -0.87 & 0.57 & 0.42 \\
\hline Percent Special Education & $-2.27 *$ & 1.05 & 0.10 \\
\hline Average Teacher Salary (in thousands of dollars) & -0.00 & 0.00 & 1.00 \\
\hline Average Teacher Years of Experience & 0.03 & 0.03 & 1.03 \\
\hline Pupil/Teacher Ratio & -0.00 & 0.02 & 1.00 \\
\hline \multicolumn{4}{|l|}{ Change in Writing Scores from 2001 to 2002} \\
\hline Intercept & $0.54 * * *$ & 0.05 & 1.72 \\
\hline School Size (per 100 students) & -0.00 & 0.00 & 1.00 \\
\hline Percent Minority & $-0.50 \sim$ & 0.27 & 0.61 \\
\hline Percent Retained in Grade & $-2.91 \sim$ & 1.72 & 0.05 \\
\hline Percent Free/Reduced-Price Lunch Eligible & 0.16 & 0.47 & 1.17 \\
\hline Percent Limited English Proficient & -0.62 & 0.64 & 0.54 \\
\hline Percent Special Education & $-2.76 *$ & 1.2 & 0.06 \\
\hline Average Teacher Salary (in thousands of dollars) & 0.00 & 0.00 & 1.00 \\
\hline Average Teacher Years of Experience & 0.01 & 0.03 & 1.01 \\
\hline Pupil/Teacher Ratio & $0.07 * * *$ & 0.02 & 1.07 \\
\hline Average Fifth-Grade Writing Level for $2000-2001$ & $-0.76 * *$ & 0.24 & 0.47 \\
\hline Use of Data for Planning/Instruction - Grade 5 & -0.01 & 0.05 & 0.99 \\
\hline \multicolumn{4}{|l|}{ Thresholds } \\
\hline$\delta_{5}$ & $2.03 * * *$ & 0.03 & \\
\hline$\delta_{4}$ & $4.11 * * *$ & 0.04 & \\
\hline$\delta_{3}$ & $6.09 * * *$ & 0.05 & \\
\hline$\delta_{2}$ & $7.50 * * *$ & 0.08 & \\
\hline Random Effect & $\begin{array}{c}\text { Variance } \\
\text { Component }\end{array}$ & & \\
\hline Baseline Writing Scores (2001) & $0.12 * * *$ & & \\
\hline Change in Writing Scores (2001-2002) & $0.11 * * *$ & & \\
\hline
\end{tabular}

$\sim p<.10, * p<.05, * * p<.01, * * * p<.001$ 
Table C6. Regression Results for Implementation of

"Use of Data for Planning and Instruction" in the Eighth Grade

\begin{tabular}{|c|c|c|c|}
\hline Fixed Effect & Estimate & $\begin{array}{c}\begin{array}{c}\text { Standard } \\
\text { Error }\end{array} \\
\end{array}$ & $\begin{array}{l}\text { Odds } \\
\text { Ratio } \\
\end{array}$ \\
\hline \multicolumn{4}{|l|}{ Baseline Writing Scores in 2001} \\
\hline Intercept & $-3.22 * * *$ & 0.06 & 0.04 \\
\hline School Size (per 100 students) & -0.00 & 0.00 & 1.00 \\
\hline Percent Minority & $-0.80 *$ & 0.32 & 0.45 \\
\hline Percent Retained in Grade & -1.50 & 1.59 & 0.22 \\
\hline Percent Free/Reduced-Price Lunch Eligible & $-1.53^{*}$ & 0.69 & 0.22 \\
\hline Percent Limited English Proficient & -0.01 & 1.53 & 0.99 \\
\hline Percent Special Education & -0.65 & 1.68 & 0.52 \\
\hline Average Teacher Salary (in thousands of dollars) & 0.00 & 0.00 & 1.00 \\
\hline Average Teacher Years of Experience & -0.01 & 0.03 & 0.99 \\
\hline Pupil/Teacher Ratio & 0.06 & 0.04 & 1.06 \\
\hline \multicolumn{4}{|l|}{ Change in Writing Scores from 2001 to 2002} \\
\hline Intercept & $0.30 * * *$ & 0.07 & 1.35 \\
\hline School Size (per 100 students) & -0.00 & 0.00 & 1.00 \\
\hline Percent Minority & $1.02 *$ & 0.47 & 2.77 \\
\hline Percent Retained in Grade & -0.67 & 2.28 & 0.51 \\
\hline Percent Free/Reduced-Price Lunch Eligible & -0.03 & 1.01 & 0.97 \\
\hline Percent Limited English Proficient & 1.31 & 2.17 & 3.71 \\
\hline Percent Special Education & 0.67 & 2.38 & 1.95 \\
\hline Average Teacher Salary (in thousands of dollars) & -0.00 & 0.00 & 1.00 \\
\hline Average Teacher Years of Experience & 0.00 & 0.04 & 1.00 \\
\hline Pupil/Teacher Ratio & -0.04 & 0.06 & 0.96 \\
\hline Average Eighth-Grade Writing Level for 2000-2001 & $2.16 * *$ & 0.66 & 8.67 \\
\hline Use of Data for Planning/Instruction - Grade 8 & $0.12 *$ & 0.05 & 1.13 \\
\hline \multicolumn{4}{|l|}{ Threshold } \\
\hline$\delta_{2}$ & $4.18 * * *$ & 0.04 & \\
\hline Random Effect & $\begin{array}{c}\text { Variance } \\
\text { Component }\end{array}$ & & \\
\hline Baseline Writing Scores (2001) & $0.07 * * *$ & & \\
\hline Change in Writing Scores (2001-2002) & $0.13 * * *$ & & \\
\hline
\end{tabular}

$\sim p<.10, * p<.05, * * p<.01, * * * p<.001$ 
Table C7. Regression Results for Implementation of "Active and Effective Leadership" in the Fifth Grade

\begin{tabular}{|c|c|c|c|}
\hline Fixed Effect & Estimate & $\begin{array}{c}\text { Standard } \\
\text { Error }\end{array}$ & $\begin{array}{l}\text { Odds } \\
\text { Ratio }\end{array}$ \\
\hline \multicolumn{4}{|l|}{ Baseline Writing Scores in 2001} \\
\hline Intercept & $-3.24 * * *$ & 0.05 & 0.04 \\
\hline School Size (per 100 students) & -0.00 & 0.00 & 1.00 \\
\hline Percent Minority & -0.10 & 0.25 & 0.90 \\
\hline Percent Retained in Grade & -0.80 & 1.51 & 0.45 \\
\hline Percent Free/Reduced-Price Lunch Eligible & $-0.87 *$ & 0.43 & 0.42 \\
\hline Percent Limited English Proficient & -0.87 & 0.58 & 0.42 \\
\hline Percent Special Education & $-2.32 *$ & 1.04 & 0.10 \\
\hline Average Teacher Salary (in thousands of dollars) & -0.00 & 0.00 & 1.00 \\
\hline Average Teacher Years of Experience & 0.03 & 0.03 & 1.03 \\
\hline Pupil/Teacher Ratio & -0.00 & 0.02 & 1.00 \\
\hline \multicolumn{4}{|l|}{ Change in Writing Scores from 2001 to 2002} \\
\hline Intercept & $0.53 * * *$ & 0.05 & 1.70 \\
\hline School Size (per 100 students) & -0.00 & 0.00 & 1.00 \\
\hline Percent Minority & $-0.57 \sim$ & 0.30 & 0.57 \\
\hline Percent Retained in Grade & -2.47 & 1.86 & 0.08 \\
\hline Percent Free/Reduced-Price Lunch Eligible & -0.47 & 0.53 & 0.63 \\
\hline Percent Limited English Proficient & $-1.26 \sim$ & 0.72 & 0.28 \\
\hline Percent Special Education & $-4.56 * * *$ & 1.32 & 0.01 \\
\hline Average Teacher Salary (in thousands of dollars) & 0.00 & 0.00 & 1.00 \\
\hline Average Teacher Years of Experience & 0.04 & 0.03 & 1.04 \\
\hline Pupil/Teacher Ratio & $0.07 * *$ & 0.02 & 1.07 \\
\hline Average Fifth-Grade Writing Level for $2000-2001$ & $-2.07 * * *$ & 0.24 & 0.13 \\
\hline Active and Effective Leadership - Grade 5 & 0.06 & 0.05 & 1.06 \\
\hline \multicolumn{4}{|l|}{ Thresholds } \\
\hline$\delta_{5}$ & $2.03 * * *$ & 0.03 & \\
\hline$\delta_{4}$ & $4.11 * * *$ & 0.04 & \\
\hline$\delta_{3}$ & $6.09 * * *$ & 0.05 & \\
\hline$\delta_{2}$ & $7.50 * * *$ & 0.08 & \\
\hline Random Effect & $\begin{array}{c}\text { Variance } \\
\text { Component }\end{array}$ & & \\
\hline Baseline Writing Scores (2001) & $0.13 * * *$ & & \\
\hline Change in Writing Scores (2001-2002) & $0.17 * * *$ & & \\
\hline
\end{tabular}

$\sim p<.10, * p<.05, * * p<.01, * * * p<.001$ 
Table C8. Regression Results for Implementation of "Active and Effective Leadership" in the Eighth Grade

\begin{tabular}{|c|c|c|c|}
\hline Fixed Effect & Estimate & $\begin{array}{c}\text { Standard } \\
\text { Error }\end{array}$ & $\begin{array}{l}\text { Odds } \\
\text { Ratio } \\
\end{array}$ \\
\hline \multicolumn{4}{|l|}{ Baseline Writing Scores in 2001} \\
\hline Intercept & $-3.22 * * *$ & 0.57 & 0.04 \\
\hline School Size (per 100 students) & -0.00 & 0.00 & 1.00 \\
\hline Percent Minority & $-0.79 *$ & 0.32 & 0.45 \\
\hline Percent Retained in Grade & -1.49 & 1.59 & 0.23 \\
\hline Percent Free/Reduced-Price Lunch Eligible & -1.55 & 0.69 & 0.21 \\
\hline Percent Limited English Proficient & 0.07 & 1.53 & 1.07 \\
\hline Percent Special Education & -0.60 & 1.68 & 0.55 \\
\hline Average Teacher Salary (in thousands of dollars) & 0.00 & 0.00 & 1.00 \\
\hline Average Teacher Years of Experience & -0.01 & 0.03 & 0.99 \\
\hline Pupil/Teacher Ratio & 0.05 & 0.04 & 1.05 \\
\hline \multicolumn{4}{|l|}{ Change in Writing Scores from 2001 to 2002} \\
\hline Intercept & $0.30 * * *$ & 0.08 & 1.35 \\
\hline School Size (per 100 students) & -0.00 & 0.00 & 1.00 \\
\hline Percent Minority & $1.08 \sim$ & 0.53 & 2.94 \\
\hline Percent Retained in Grade & -0.87 & 2.64 & 0.42 \\
\hline Percent Free/Reduced-Price Lunch Eligible & 0.25 & 1.14 & 1.28 \\
\hline Percent Limited English Proficient & 1.23 & 2.49 & 3.42 \\
\hline Percent Special Education & 1.04 & 2.72 & 2.83 \\
\hline Average Teacher Salary (in thousands of dollars) & -0.00 & 0.00 & 1.00 \\
\hline Average Teacher Years of Experience & -0.00 & 0.05 & 1.00 \\
\hline Pupil/Teacher Ratio & -0.06 & 0.06 & 0.94 \\
\hline Average Eighth-Grade Writing Level for 2000-2001 & $2.98 * * *$ & 0.71 & 19.69 \\
\hline Active and Effective Leadership - Grade 8 & 0.09 & 0.06 & 1.09 \\
\hline \multicolumn{4}{|l|}{ Threshold } \\
\hline$\delta_{2}$ & $4.18 * * *$ & 0.04 & \\
\hline Random Effect & $\begin{array}{c}\text { Variance } \\
\text { Component }\end{array}$ & & \\
\hline Baseline Writing Scores (2001) & $0.07 * * *$ & & \\
\hline Change in Writing Scores (2001-2002) & $0.19 * * *$ & & \\
\hline
\end{tabular}

$\sim p<.10, * p<.05, * * p<.01, * * * p<.001$ 
Table C9. Regression Results for Implementation of "Parent and Community Involvement" in the Fifth Grade

\begin{tabular}{|c|c|c|c|}
\hline Fixed Effect & Estimate & $\begin{array}{l}\text { Standard } \\
\text { Error }\end{array}$ & $\begin{array}{l}\text { Odds } \\
\text { Ratio }\end{array}$ \\
\hline \multicolumn{4}{|l|}{ Baseline Writing Scores in 2001} \\
\hline Intercept & $-3.24 * * *$ & 0.05 & 0.04 \\
\hline School Size (per 100 students) & -0.00 & 0.00 & 1.00 \\
\hline Percent Minority & -0.11 & 0.25 & 0.90 \\
\hline Percent Retained in Grade & 0.73 & 1.51 & 2.08 \\
\hline Percent Free/Reduced-Price Lunch Eligible & $-0.86 *$ & 0.43 & 0.42 \\
\hline Percent Limited English Proficient & -0.87 & 0.58 & 0.42 \\
\hline Percent Special Education & $-2.27^{*}$ & 1.05 & 0.10 \\
\hline Average Teacher Salary (in thousands of dollars) & -0.00 & 0.00 & 1.00 \\
\hline Average Teacher Years of Experience & 0.03 & 0.03 & 1.03 \\
\hline Pupil/Teacher Ratio & -0.00 & -0.02 & 1.00 \\
\hline \multicolumn{4}{|l|}{ Change in Writing Scores from 2001 to 2002} \\
\hline Intercept & $0.54 * * *$ & 0.05 & 1.72 \\
\hline School Size (per 100 students) & -0.00 & 0.00 & 1.00 \\
\hline Percent Minority & $-0.51 \sim$ & 0.27 & 0.60 \\
\hline Percent Retained in Grade & $-2.93 \sim$ & 1.65 & 0.05 \\
\hline Percent Free/Reduced-Price Lunch Eligible & 0.08 & 0.47 & 1.08 \\
\hline Percent Limited English Proficient & -0.70 & 0.64 & 0.50 \\
\hline Percent Special Education & $-2.96 *$ & 1.20 & 0.05 \\
\hline Average Teacher Salary (in thousands of dollars) & 0.00 & 0.00 & 1.00 \\
\hline Average Teacher Years of Experience & 0.01 & 0.03 & 1.01 \\
\hline Pupil/Teacher Ratio & $0.07 * * *$ & 0.02 & 1.07 \\
\hline Average Fifth-Grade Writing Level for 2000-2001 & $-0.91 * * *$ & 0.24 & 0.40 \\
\hline Parent and Community Involvement - Grade 5 & 0.01 & 0.05 & 1.01 \\
\hline \multicolumn{4}{|l|}{ Thresholds } \\
\hline$\delta_{5}$ & $2.03 * * *$ & 0.03 & \\
\hline$\delta_{4}$ & $4.11 * * *$ & 0.04 & \\
\hline$\delta_{3}$ & $6.09 * * *$ & 0.05 & \\
\hline$\delta_{2}$ & $7.50 * * *$ & 0.08 & \\
\hline Random Effect & $\begin{array}{c}\text { Variance } \\
\text { Component } \\
\end{array}$ & & \\
\hline Baseline Writing Scores (2001) & $0.12 * * *$ & & \\
\hline Change in Writing Scores (2001-2002) & $0.11 * * *$ & & \\
\hline
\end{tabular}

$\sim p<.10, * p<.05, * * p<.01, * * * p<.001$ 
Table C10. Regression Results for Implementation of "Parent and Community Involvement" in the Eighth Grade

\begin{tabular}{|c|c|c|c|}
\hline Fixed Effect & Estimate & $\begin{array}{l}\text { Standard } \\
\text { Error }\end{array}$ & $\begin{array}{l}\text { Odds } \\
\text { Ratio }\end{array}$ \\
\hline \multicolumn{4}{|l|}{ Baseline Writing Scores in 2001} \\
\hline Intercept & $-3.21 * * *$ & 0.06 & 0.04 \\
\hline School Size (per 100 students) & -0.00 & 0.00 & 1.00 \\
\hline Percent Minority & $-0.80 *$ & 0.32 & 0.45 \\
\hline Percent Retained in Grade & -1.50 & 1.59 & 0.22 \\
\hline Percent Free/Reduced-Price Lunch Eligible & $-1.52 *$ & 0.69 & 0.22 \\
\hline Percent Limited English Proficient & -0.02 & 1.53 & 0.98 \\
\hline Percent Special Education & -0.66 & 1.68 & 0.52 \\
\hline Average Teacher Salary (in thousands of dollars) & 0.00 & 0.00 & 1.00 \\
\hline Average Teacher Years of Experience & -0.01 & 0.03 & 0.99 \\
\hline Pupil/Teacher Ratio & 0.06 & 0.04 & 1.06 \\
\hline \multicolumn{4}{|l|}{ Change in Writing Scores from 2001 to 2002} \\
\hline Intercept & $0.30 * * *$ & 0.07 & 1.35 \\
\hline School Size (per 100 students) & -0.00 & 0.00 & 1.00 \\
\hline Percent Minority & $0.90 \sim$ & 0.50 & 2.46 \\
\hline Percent Retained in Grade & -0.48 & 2.35 & 0.62 \\
\hline Percent Free/Reduced-Price Lunch Eligible & 0.14 & 1.04 & 1.15 \\
\hline Percent Limited English Proficient & 0.85 & 2.25 & 2.34 \\
\hline Percent Special Education & 0.73 & 2.54 & 2.08 \\
\hline Average Teacher Salary (in thousands of dollars) & -0.00 & 0.00 & 1.00 \\
\hline Average Teacher Years of Experience & -0.01 & 0.05 & 0.99 \\
\hline Pupil/Teacher Ratio & -0.08 & 0.06 & 0.92 \\
\hline Average Eighth-Grade Writing Level for $2000-2001$ & $2.37 * *$ & 0.72 & 10.70 \\
\hline Parent and Community Involvement - Grade 8 & 0.00 & 0.06 & 1.00 \\
\hline \multicolumn{4}{|l|}{ Threshold } \\
\hline$\delta_{2}$ & $4.18 * * *$ & 0.04 & \\
\hline Random Effect & $\begin{array}{c}\text { Variance } \\
\text { Component } \\
\end{array}$ & & \\
\hline Baseline Writing Scores (2001) & $0.07 * * *$ & & \\
\hline Change in Writing Scores (2001-2002) & $0.15 * * *$ & & \\
\hline
\end{tabular}


Table C11. Regression Results for Implementation of "School-Level Structural Elements" in the Fifth Grade

\begin{tabular}{|c|c|c|c|}
\hline Fixed Effect & Estimate & $\begin{array}{c}\text { Standard } \\
\text { Error }\end{array}$ & $\begin{array}{l}\text { Odds } \\
\text { Ratio }\end{array}$ \\
\hline \multicolumn{4}{|l|}{ Baseline Writing Scores in 2001} \\
\hline Intercept & $-3.24 * * *$ & 0.05 & 0.04 \\
\hline School Size (per 100 students) & -0.00 & 0.00 & 1.00 \\
\hline Percent Minority & -0.11 & 0.25 & 0.90 \\
\hline Percent Retained in Grade & 0.73 & 1.50 & 2.08 \\
\hline Percent Free/Reduced-Price Lunch Eligible & $-0.86 *$ & 0.58 & 0.42 \\
\hline Percent Limited English Proficient & -0.87 & 1.05 & 0.42 \\
\hline Percent Special Education & $-2.27 *$ & 0.00 & 0.10 \\
\hline Average Teacher Salary (in thousands of dollars) & -0.00 & 0.03 & 1.00 \\
\hline Average Teacher Years of Experience & 0.03 & 0.02 & 1.03 \\
\hline Pupil/Teacher Ratio & -0.00 & 0.02 & 1.00 \\
\hline \multicolumn{4}{|l|}{ Change in Writing Scores from 2001 to 2002} \\
\hline Intercept & $0.54 * * *$ & 0.05 & 1.72 \\
\hline School Size (per 100 students) & -0.00 & 0.00 & 1.00 \\
\hline Percent Minority & $-0.52 \sim$ & 0.27 & 0.59 \\
\hline Percent Retained in Grade & $-3.01 \sim$ & 1.67 & 0.05 \\
\hline Percent Free/Reduced-Price Lunch Eligible & 0.05 & 0.47 & 1.05 \\
\hline Percent Limited English Proficient & -0.71 & 0.34 & 0.49 \\
\hline Percent Special Education & $-3.08 * *$ & 1.20 & 0.05 \\
\hline Average Teacher Salary (in thousands of dollars) & 0.00 & 0.00 & 1.00 \\
\hline Average Teacher Years of Experience & 0.01 & 0.03 & 1.01 \\
\hline Pupil/Teacher Ratio & $0.07 * * *$ & 0.02 & 1.07 \\
\hline Average Fifth-Grade Writing Level for $2000-2001$ & $-0.97 * * *$ & 0.05 & 0.38 \\
\hline School-Level Structural Elements - Grade 5 & 0.02 & 0.05 & 1.02 \\
\hline \multicolumn{4}{|l|}{ Thresholds } \\
\hline$\delta_{5}$ & $2.03 * * *$ & 0.03 & \\
\hline$\delta_{4}$ & $4.11 * * *$ & 0.04 & \\
\hline$\delta_{3}$ & $6.09 * * *$ & 0.05 & \\
\hline$\delta_{2}$ & $7.50 * * *$ & 0.08 & \\
\hline Random Effect & $\begin{array}{c}\text { Variance } \\
\text { Component }\end{array}$ & & \\
\hline Baseline Writing Scores (2001) & $0.12 * * *$ & & \\
\hline Change in Writing Scores (2001-2002) & $0.11 * * *$ & & \\
\hline
\end{tabular}

$\sim p<.10, * p<.05, * * p<.01, * * * p<.001$ 
Table C12. Regression Results for Implementation of "School-Level Structural Elements" in the Eighth Grade

\begin{tabular}{|c|c|c|c|}
\hline Fixed Effect & Estimate & $\begin{array}{l}\text { Standard } \\
\text { Error }\end{array}$ & $\begin{array}{l}\text { Odds } \\
\text { Ratio }\end{array}$ \\
\hline \multicolumn{4}{|l|}{ Baseline Writing Scores in 2001} \\
\hline Intercept & $-3.22 * * *$ & 0.06 & 0.04 \\
\hline School Size (per 100 students) & -0.00 & 0.00 & 1.00 \\
\hline Percent Minority & $-0.80 *$ & 0.32 & 0.45 \\
\hline Percent Retained in Grade & -1.50 & 1.59 & 0.22 \\
\hline Percent Free/Reduced-Price Lunch Eligible & $-1.51 *$ & 0.69 & 0.22 \\
\hline Percent Limited English Proficient & -0.05 & 1.53 & 0.95 \\
\hline Percent Special Education & -0.67 & 1.68 & 0.51 \\
\hline Average Teacher Salary (in thousands of dollars) & 0.00 & 0.00 & 1.00 \\
\hline Average Teacher Years of Experience & -0.01 & 0.03 & 0.99 \\
\hline Pupil/Teacher Ratio & 0.06 & 0.04 & 1.06 \\
\hline \multicolumn{4}{|l|}{ Change in Writing Scores from 2001 to 2002} \\
\hline Intercept & $0.31 * * *$ & 0.07 & 1.36 \\
\hline School Size (per 100 students) & -0.00 & 0.00 & 1.00 \\
\hline Percent Minority & $0.82 \sim$ & 0.48 & 2.27 \\
\hline Percent Retained in Grade & -0.48 & 2.28 & 0.62 \\
\hline Percent Free/Reduced-Price Lunch Eligible & 0.08 & 1.01 & 1.08 \\
\hline Percent Limited English Proficient & 0.81 & 2.16 & 2.25 \\
\hline Percent Special Education & 0.65 & 2.38 & 1.92 \\
\hline Average Teacher Salary (in thousands of dollars) & -0.00 & 0.00 & 1.00 \\
\hline Average Teacher Years of Experience & -0.01 & 0.04 & 0.99 \\
\hline Pupil/Teacher Ratio & -0.08 & 0.06 & 0.92 \\
\hline Average Eighth-Grade Writing Level for 2000-2001 & $2.10 * *$ & 0.06 & 8.17 \\
\hline School-Level Structural Elements - Grade 8 & -0.03 & 0.06 & 0.97 \\
\hline \multicolumn{4}{|l|}{ Threshold } \\
\hline$\delta_{2}$ & $4.18 * * *$ & 0.04 & \\
\hline Random Effect & $\begin{array}{c}\text { Variance } \\
\text { Component }\end{array}$ & & \\
\hline Baseline Writing Scores (2001) & $0.07 * * *$ & & \\
\hline Change in Writing Scores (2001-2002) & $0.13 * * *$ & & \\
\hline
\end{tabular}

$\sim p<.10, * p<.05, * * p<.01, * * * p<.001$ 
Table C13. Regression Results for Implementation of "Understanding of the America's Choice Design" in the Fifth Grade

\begin{tabular}{|c|c|c|c|}
\hline Fixed Effect & Estimate & $\begin{array}{c}\text { Standard } \\
\text { Error }\end{array}$ & $\begin{array}{l}\text { Odds } \\
\text { Ratio } \\
\end{array}$ \\
\hline \multicolumn{4}{|l|}{ Baseline Writing Scores in 2001} \\
\hline Intercept & $-3.25 * * *$ & 0.05 & 0.04 \\
\hline School Size (per 100 students) & -0.00 & 0.00 & 1.00 \\
\hline Percent Minority & -0.12 & 0.25 & 0.89 \\
\hline Percent Retained in Grade & 0.74 & 1.52 & 2.10 \\
\hline Percent Free/Reduced-Price Lunch Eligible & $-0.87 *$ & 0.43 & 0.42 \\
\hline Percent Limited English Proficient & -0.86 & 0.58 & 0.42 \\
\hline Percent Special Education & $-2.27 *$ & 1.05 & 0.10 \\
\hline Average Teacher Salary (in thousands of dollars) & -0.00 & 0.00 & 1.00 \\
\hline Average Teacher Years of Experience & 0.03 & 0.03 & 1.03 \\
\hline Pupil/Teacher Ratio & -0.00 & 0.02 & 1.00 \\
\hline \multicolumn{4}{|l|}{ Change in Writing Scores from 2001 to 2002} \\
\hline Intercept & $0.54 * * *$ & 0.05 & 1.72 \\
\hline School Size (per 100 students) & -0.00 & 0.00 & 1.00 \\
\hline Percent Minority & $-0.51 \sim$ & 0.27 & 0.60 \\
\hline Percent Retained in Grade & $-3.00 \sim$ & 1.70 & 0.05 \\
\hline Percent Free/Reduced-Price Lunch Eligible & 0.15 & 0.48 & 1.16 \\
\hline Percent Limited English Proficient & -0.64 & 0.65 & 0.53 \\
\hline Percent Special Education & $-2.80 *$ & 1.21 & 0.06 \\
\hline Average Teacher Salary (in thousands of dollars) & 0.00 & 0.00 & 1.00 \\
\hline Average Teacher Years of Experience & 0.01 & 0.03 & 1.01 \\
\hline Pupil/Teacher Ratio & $0.07 * * *$ & 0.02 & 1.07 \\
\hline Average Fifth-Grade Writing Level for 2000-2001 & $-0.77 * *$ & 0.24 & 0.46 \\
\hline $\begin{array}{l}\text { Understanding of the America's Choice Design - Grade } \\
5\end{array}$ & -0.00 & 0.05 & 1.00 \\
\hline \multicolumn{4}{|l|}{ Thresholds } \\
\hline$\delta_{5}$ & $2.04 * * *$ & 0.03 & \\
\hline$\delta_{4}$ & $4.12 * * *$ & 0.04 & \\
\hline$\delta 3$ & $6.09 * * *$ & 0.05 & \\
\hline$\delta_{2}$ & $7.51 * * *$ & 0.08 & \\
\hline Random Effect & $\begin{array}{c}\text { Variance } \\
\text { Component }\end{array}$ & & \\
\hline Baseline Writing Scores (2001) & $0.13 * * *$ & & \\
\hline Change in Writing Scores (2001-2002) & $0.12 * * *$ & & \\
\hline
\end{tabular}

$\sim p<.10, * p<.05, * * p<.01, * * * p<.001$ 
Table C14. Regression Results for Implementation of "Understanding of the America's Choice Design" in the Eighth Grade

\begin{tabular}{|c|c|c|c|}
\hline Fixed Effect & Estimate & $\begin{array}{c}\text { Standard } \\
\text { Error }\end{array}$ & $\begin{array}{l}\text { Odds } \\
\text { Ratio }\end{array}$ \\
\hline \multicolumn{4}{|l|}{ Baseline Writing Scores in 2001} \\
\hline Intercept & $-3.22 * * *$ & 0.06 & 0.04 \\
\hline School Size (per 100 students) & -0.00 & 0.00 & 1.00 \\
\hline Percent Minority & $-0.80 *$ & 0.32 & 0.45 \\
\hline Percent Retained in Grade & -1.50 & 1.59 & 0.22 \\
\hline Percent Free/Reduced-Price Lunch Eligible & $-1.52 *$ & 0.69 & 0.22 \\
\hline Percent Limited English Proficient & -0.03 & 1.53 & 0.97 \\
\hline Percent Special Education & -0.66 & 1.68 & 0.52 \\
\hline Average Teacher Salary (in thousands of dollars) & 0.00 & 0.00 & 1.00 \\
\hline Average Teacher Years of Experience & -0.01 & 0.03 & 0.99 \\
\hline Pupil/Teacher Ratio & 0.06 & 0.04 & 1.06 \\
\hline \multicolumn{4}{|l|}{ Change in Writing Scores from 2001 to 2002} \\
\hline Intercept & $0.30 * * *$ & 0.07 & 1.35 \\
\hline School Size (per 100 students) & -0.00 & 0.00 & 1.00 \\
\hline Percent Minority & $0.88 \sim$ & 0.49 & 2.41 \\
\hline Percent Retained in Grade & -0.42 & 2.34 & 0.66 \\
\hline Percent Free/Reduced-Price Lunch Eligible & 0.19 & 1.06 & 1.21 \\
\hline Percent Limited English Proficient & 0.71 & 2.26 & 2.03 \\
\hline Percent Special Education & 0.67 & 2.44 & 1.95 \\
\hline Average Teacher Salary (in thousands of dollars) & -0.00 & 0.00 & 1.00 \\
\hline Average Teacher Years of Experience & -0.01 & 0.05 & 0.99 \\
\hline Pupil/Teacher Ratio & -0.08 & 0.07 & 0.92 \\
\hline Average Eighth-Grade Writing Level for 2000-2001 & $2.38 * *$ & 0.74 & 10.80 \\
\hline $\begin{array}{l}\text { Understanding of the America's Choice Design - Grade } \\
8\end{array}$ & -0.02 & 0.07 & 0.98 \\
\hline \multicolumn{4}{|l|}{ Threshold } \\
\hline$\delta_{2}$ & $4.18 * * *$ & 0.04 & \\
\hline Random Effect & $\begin{array}{c}\text { Variance } \\
\text { Component }\end{array}$ & & \\
\hline Baseline Writing Scores (2001) & $0.07 * * *$ & & \\
\hline Change in Writing Scores (2001-2002) & $0.14 * * *$ & & \\
\hline
\end{tabular}

